4

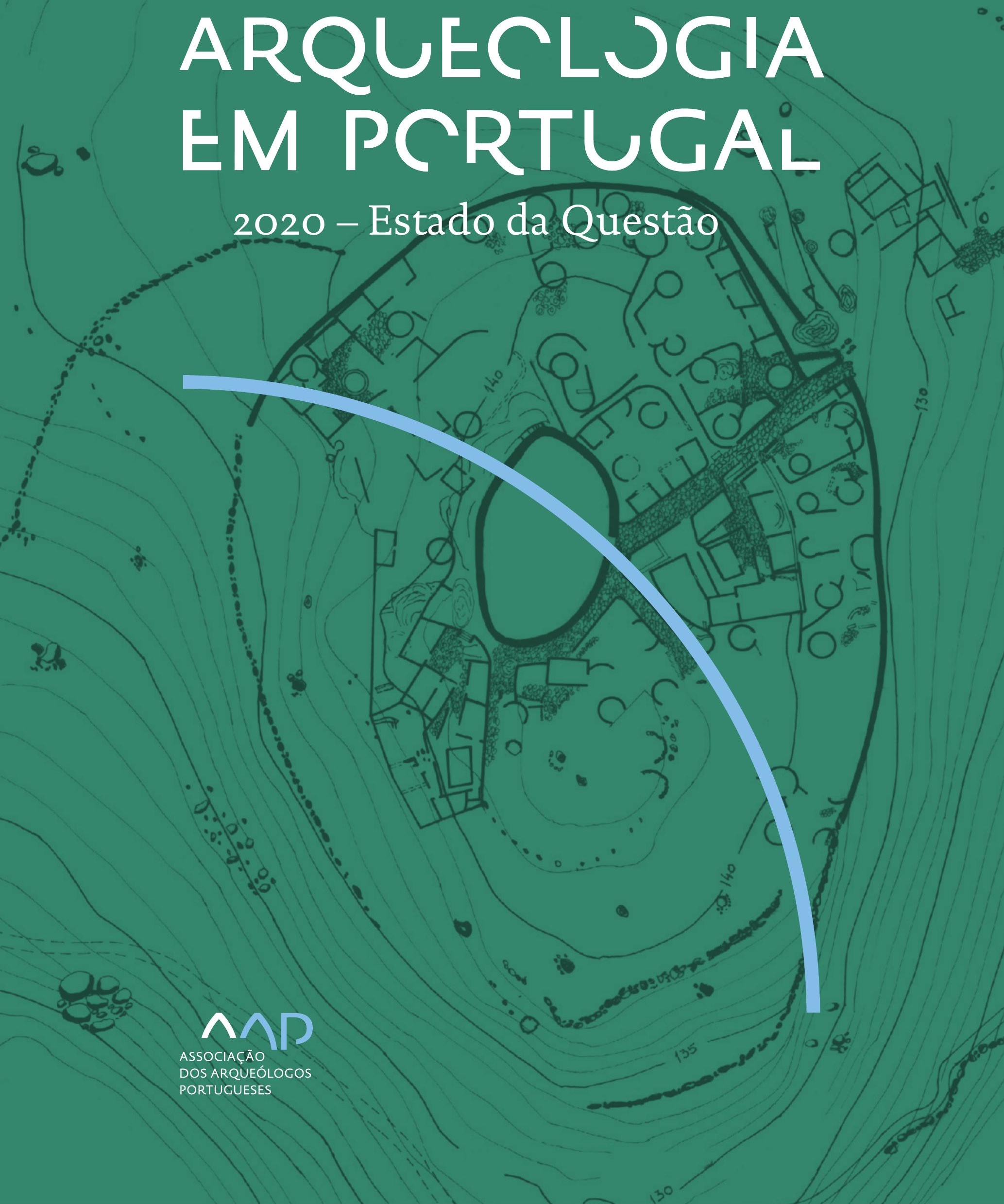


Coordenação editorial: José Morais Arnaud, César Neves e Andrea Martins Design gráfico: Flatland Design

AAP - ISBN: 978-972-9451-89-8

CITCEM - ISBN: 978-989-8970-25-1

Associação dos Arqueólogos Portugueses e CITCEM

Lisboa, 2020

O conteúdo dos artigos é da inteira responsabilidade dos autores. Sendo assim a Associação dos Arqueólogos Portugueses declina qualquer responsabilidade por eventuais equívocos ou questões de ordem ética e legal.

Desenho de capa:

Planta do castro de Monte Mozinho (Museu Municipal de Penafiel).

\section{$\hat{\wedge} \mathrm{P}$}

DOS ARQUEÓLOGOS PORTUGUESES

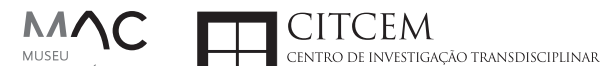
MUSEU
ARQUELLÓGICO
DO CARMO
U.PORTO

FLUP FACULDADE DE LETRAS
UNIVERSIDADE DO PORTO

Apoio

EC para a Ciência 


\section{Índice}

15 Prefácio

José Morais Arnaud

\section{Historiografia e Teoria}

17 Território, comunidade, memória e emoção: a contribuição da história da arqueologia (algumas primeiras e breves reflexões)

Ana Cristina Martins

25 Como descolonizar a arqueologia portuguesa?

Rui Gomes Coelho

41 Arqueologia e Modernidade: uma revisitação pessoal e breve de alguns aspetos da obra homónima de Julian Thomas de 2004

Vítor Oliveira Jorge

57 Dados para a História das Mulheres na Arqueologia portuguesa, dos finais do século XIX aos inícios do século XX: números, nomes e tabelas

Filipa Dimas / Mariana Diniz

73 Retractos da arqueologia portuguesa na imprensa: (in)visibilidades no feminino

Catarina Costeira / Elsa Luís

85 Arqueologia e Arqueólogos no Norte de Portugal Jacinta Bugalhão

101 Vieira Guimarães (1864-1939) e a arqueologia em Tomar: uma abordagem sobre o território e as gentes

João Amendoeira Peixoto / Ana Cristina Martins

115 Os memoráveis? A arqueologia algarvia na imprensa nacional e regional na presente centúria (2001-2019): características, visões do(s) passado(s) e a arqueologia

enquanto marca

Frederico Agosto / João Silva

129 A Evolução da Arqueologia Urbana e a Valorização Patrimonial no Barlavento Algarvio: Os casos de Portimão e Silves

Artur Mateus / Diogo Varandas / Rafael Boavida

\section{Gestão, Valorização e Salvaguarda do Património}

145 O Caderno Reivindicativo e as condições de trabalho em Arqueologia Miguel Rocha / Liliana Matias Carvalho / Regis Barbosa / Mauro Correia / Sara Simões / Jacinta Bugalhão / Sara Brito / Liliana Veríssimo Carvalho / Richard Peace / Pedro Peça / Cézer Santos

155 Os Estudos de Impacte Patrimonial como elemento para uma estratégia sustentável de minimização de impactes no âmbito de reconversões agrícolas Tiago do Pereiro

165 Salvaguarda de Património arqueológico em operações florestais: gestão e sensibilização Filipa Bragança / Gertrudes Zambujo / Sandra Lourenço / Belém Paiva / Carlos Banha / Frederico Tatá Regala / Helena Moura / Jacinta Bugalhão / João Marques / José Correia / Pedro Faria / Samuel Melro

179 Os valores do Património: uma investigação sobre os Sítios Pré-históricos de Arte Rupestre do Vale do Rio Côa e de Siega Verde José Paulo Francisco 
189 Conjugando recursos arqueológicos e naturais para potenciar as visitas ao Geoparque Litoral de Viana do Castelo (Noroeste de Portugal)

Hugo A. Sampaio / Ana M.S. Bettencourt / Susana Marinho / Ricardo Carvalhido

203 Áreas de Potencial Arqueológico na Região do Médio Tejo: Modelo Espacial Preditivo Rita Ferreira Anastácio / Ana Filipa Martins / Luiz Oosterbeek

223 Património Arqueológico e Gestão Territorial: O contributo da Arqueologia para a revisão do PDM de Avis

Ana Cristina Ribeiro

237 A coleção arqueológica do extinto Museu Municipal do Porto - Origens, Percursos e Estudos

Sónia Couto

251 Valpaços - uma nova carta arqueológica

Pedro Pereira / Maria de Fátima Casares Machado

263 Arqueologia na Cidade de Peniche

Adriano Constantino / Luís Rendeiro

273 Arqueologia Urbana: a cidade de Lagos como caso de Estudo Cátia Neto

285 Estratégias de promoção do património cultural subaquático nos Açores. O caso da ilha do Faial

José Luís Neto / José Bettencourt / Luís Borges / Pedro Parreira

297 Carta Arqueológica da Cidade Velha: Uma primeira abordagem

Jaylson Monteiro / Nireide Tavares / Sara da Veiga / Claudino Ramos / Edson Brito /

Carlos Carvalho / Francisco Moreira / Adalberto Tavares

311 Antropologia Virtual: novas metodologias para a análise morfológica e funcional Ricardo Miguel Godinho / Célia Gonçalves

\section{Didáctica da Arqueologia}

327 Como os projetos de Arqueologia podem contribuir para uma comunidade culturalmente mais consciente Alexandra Figueiredo / Claúdio Monteiro / Adolfo Silveira / Ricardo Lopes

337 Educação Patrimonial - Um cidadão esclarecido é um cidadão ativo! Ana Paula Almeida

351 A aproximação da Arqueologia à sala de aula: um caso de estudo no $3^{\circ}$ ciclo do Ensino Básico Luís Serrão Gil

363 Arqueologia 3.o - Pensar e comunicar a Arqueologia para um futuro sustentável Mónica Rolo

377 “Conversa de Arqueólogos" - Divulgar a Arqueologia em tempos de Pandemia Diogo Teixeira Dias

389 Escola Profissional de Arqueologia: desafios e oportunidades Susana Nunes / Dulcineia Pinto / Júlia Silva / Ana Mascarenhas

399 Os Museus de Arqueologia e os Jovens: a oferta educativa para o público adolescente Beatriz Correia Barata / Leonor Medeiros

411 O museu universitário como mediador entre a ciência e a sociedade: o exemplo da secção de arqueologia no Museu de História Natural e da Ciência da Universidade do Porto (MHNC-UP)

Rita Gaspar 
421 Museu de Lanifícios: Real Fábrica de Panos. Atividades no âmbito da Arqueologia Beatriz Correia Barata / Rita Salvado

427 Arqueologia Pública e o caso da localidade da Mata (Torres Novas) Cláudia Manso / Ana Rita Ferreira / Cristiana Ferreira / Vanessa Cardoso Antunes

431 Do sítio arqueológico ao museu: um percurso (também) didático Lídia Fernandes

447 Estão todos convidados para a Festa! E para dançar também... O projecto do Serviço Educativo do Museu Arqueológico do Carmo na $5^{\underline{a}}$ Edição da Festa da Arqueologia Rita Pires dos Santos

459 O “Clã de Carenque”, um projeto didático de arqueologia Eduardo Gonzalez Rocha

469 Mediação cultural: peixe que puxa carroça nas Ruínas Romanas de Troia Inês Vaz Pinto / Ana Patrícia Magalhães / Patrícia Brum / Filipa Santos

481 Didática Arqueológica, experiências do Projeto Mértola Vila Museu Maria de Fátima Palma / Clara Rodrigues / Susana Gómez / Lígia Rafael

\section{Arte Rupestre}

497 Os inventários de arte rupestre em Portugal Mila Simões de Abreu

513 O projeto FIRST-ART - conservação, documentação e gestão das primeiras manifestações de arte rupestre no Sudoeste da Península Ibérica: as grutas do Escoural e Maltravieso Sara Garcês / Hipólito Collado / José Julio García Arranz / Luiz Oosterbeek / António Carlos Silva / Pierluigi Rosina / Hugo Gomes / Anabela Borralheiro Pereira / George Nash / Esmeralda Gomes / Nelson Almeida / Carlos Carpetudo

523 Trabalhos de documentação de arte paleolítica realizados no âmbito do projeto PalæoCôa André Tomás Santos / António Fernando Barbosa / Luís Luís / Marcelo Silvestre / Thierry Aubry

537 Imagens fantasmagóricas, silhuetas elusivas: as figuras humanas na arte do Paleolítico Superior da região do Côa Mário Reis

$55^{1}$ Os motivos zoomórficos representados nas placas de tear de Vila Nova de São Pedro (Azambuja, Portugal) Andrea Martins / César Neves / José M. Arnaud / Mariana Diniz

571 Arte Rupestre do Monte de Góios (Lanhelas, Caminha). Síntese dos resultados dos trabalhos efectuados em 2007-2009 Mário Varela Gomes

599 Gravuras rupestres de barquiformes no Monte de S. Romão, Guimarães, Noroeste de Portugal Daniela Cardoso

613 Círculos segmentados gravados na Bacia do Rio Lima (Noroeste de Portugal): contributos para o seu estudo Diogo Marinho / Ana M.S. Bettencourt / Hugo Aluai Sampaio

631 Equídeos gravados no curso inferior do Rio Mouro, Monção (NW Portugal). Análise preliminar Coutinho, L.M. / Bettencourt, A.M.S / Sampaio, Hugo A.S

645 Paletas na Arte Rupestre do Noroeste de Portugal. Inventário preliminar Bruna Sousa Afonso / Ana M. S. Bettencourt / Hugo A. Sampaio 


\section{Pré-História}

661 O projeto Miño/Minho: balanço de quatro anos de trabalhos arqueológicos Sérgio Monteiro-Rodrigues / João Pedro Cunha-Ribeiro / Eduardo Méndez-Quintas / Carlos Ferreira / Pedro Xavier / José Meireles / Alberto Gomes / Manuel Santonja / Alfredo Pérez-González

677 A ocupação paleolítica da margem esquerda do Baixo Minho: a indústria lítica do sítio de Pedreiras 2 (Monção, Portugal) e a sua integração no contexto regional Carlos Ferreira / João Pedro Cunha-Ribeiro / Sérgio Monteiro-Rodrigues / Eduardo Méndez-Quintas / Pedro Xavier / José Meireles / Alberto Gomes / Manuel Santonja / Alfredo Pérez-González

693 O sítio acheulense do Plistocénico médio da Gruta da Aroeira Joan Daura / Montserrat Sanz / Filipa Rodrigues / Pedro Souto / João Zilhão

703 As sociedades neandertais no Barlavento algarvio: modelos preditivos com recurso aos SIG

Daniela Maio

715 A utilização de quartzo durante o Paleolítico Superior no território dos vales dos rios Vouga e Côa

Cristina Gameiro / Thierry Aubry / Bárbara Costa / Sérgio Gomes / Luís Luís / Carmen Manzano / André Tomás Santos

733 Uma perspetiva diacrónica da ocupação do concheiro do Cabeço da Amoreira (Muge, Portugal) a partir da tecnologia lítica Joana Belmiro / João Cascalheira / Célia Gonçalves

745 Novos dados sobre a Pré-história Antiga no concelho de Palmela. A intervenção arqueológica no sítio do Poceirão I

Michelle Teixeira Santos

757 Problemas em torno de Datas Absolutas Pré-Históricas no Norte do Alentejo Jorge de Oliveira

771 Povoamento pré-histórico nas áreas montanhosas do NO de Portugal: o Abrigo 1 de Vale de Cerdeira Pedro Xavier / José Meireles / Carlos Alves

783 Apreciação do povoamento do Neolítico Inicial na Baixa Bacia do Douro. A Lavra I (Serra da Aboboreira) como caso de estudo Maria de Jesus Sanches

797 O Processo de Neolitização na Plataforma do Mondego: os dados do Sector C do Outeiro dos Castelos de Beijós (Carregal do Sal)

João Carlos de Senna-Martinez / José Manuel Quintã Ventura / Andreia Carvalho / Cíntia Maurício

823 Novos trabalhos na Lapa da Bugalheira (Almonda, Torres Novas) Filipa Rodrigues / Pedro Souto / Artur Ferreira / Alexandre Varanda / Luís Gomes / Helena Gomes / João Zilhão

837 A pedra polida e afeiçoada do sítio do Neolítico médio da Moita do Ourives (Benavente, Portugal)

César Neves

857 Casal do Outeiro (Encarnação, Mafra): novos contributos para o conhecimento do povoamento do Neolítico final na Península de Lisboa.

Cátia Delicado / Carlos Maneira e Costa / Marta Miranda / Ana Catarina Sousa

873 Stresse infantil, morbilidade e mortalidade no sítio arqueológico do Neolítico Final/ Calcolítico ( $4^{\circ}$ e $3^{\circ}$ milénio a.C.) do Monte do Carrascal 2 (Ferreira do Alentejo, Beja) Liliana Matias de Carvalho / Sofia N. Wasterlain 
885 Come together: O Conjunto Megalítico das Motas (Monção, Viana do Castelo) e as expressões Campaniformes do Alto Minho Ana Catarina Basílio / Rui Ramos

899 Trabalhos arqueológicos no sítio Calcolítico da Pedreira do Poio Carla Magalhães / João Muralha / Mário Reis / António Batarda Fernandes

913 O sítio arqueológico de Castanheiro do Vento. Da arquitectura do sítio à arquitectura de um território João Muralha Cardoso

925 Estudo zooarqueológico das faunas do Calcolítico final de Vila Nova de São Pedro (Azambuja, Portugal): Campanhas de 2017 e 2018 Cleia Detry / Ana Catarina Francisco / Mariana Diniz / Andrea Martins / César Neves / José Morais Arnaud

943 As faunas depositadas no Museu Arqueológico do Carmo provenientes de Vila Nova de São Pedro (Azambuja): as campanhas de 1937 a 1967 Ana Catarina Francisco / Cleia Detry / César Neves / Andrea Martins / Mariana Diniz / José Morais Arnaud

959 Análise funcional de material lítico em sílex do castro de Vila Nova de S. Pedro (Azambuja, Portugal): uma primeira abordagem Rafael Lima

971 O recinto da Folha do Ouro 1 (Serpa) no contexto dos recintos de fossos calcolíticos alentejanos

António Carlos Valera / Tiago do Pereiro / Pedro Valério / António M. Monge Soares

\section{Proto-História}

987 Produção de sal marinho na Idade do Bronze do noroeste Português. Alguns dados para uma reflexão

Ana M. S. Bettencourt / Sara Luz / Nuno Oliveira / Pedro P. Simões / Maria Isabel C. Alves / Emílio Abad-Vidal

1001 A estátua-menir do Pedrão ou de São Bartolomeu do Mar (Esposende, noroeste de Portugal) no contexto arqueológico da fachada costeira de entre os rios Neiva e Cávado Ana M. S. Bettencourt / Manuel Santos-Estévez / Pedro Pimenta Simões / Luís Gonçalves

1015 O Castro do Muro (Vandoma/Baltar, Paredes) - notas para uma biografia de ocupação da Idade do Bronze à Idade Média

Maria Antónia D. Silva / Ana M. S. Bettencourt / António Manuel S. P. Silva / Natália Félix

1031 Do Bronze Final à Idade Média - continuidades e hiatos na ocupação de Povoados em Oliveira de Azeméis João Tiago Tavares / Adriaan de Man

1041 As faunas do final da Idade do Bronze no Sul de Portugal: leituras desde o Outeiro do Circo (Beja)

Nelson J. Almeida / Íris Dias / Cleia Detry / Eduardo Porfírio / Miguel Serra

1055 A Espada do Monte das Oliveiras (Serpa) - uma arma do Bronze Pleno do Sudoeste Rui M. G. Monge Soares / Pedro Valério / Mariana Nabais / António M. Monge Soares

1065 São Julião da Branca (Albergaria-a-Velha) - Investigação e valorização de um povoado do Bronze Final

António Manuel S. P. Silva / Paulo A. P. Lemos / Sara Almeida e Silva / Edite Martins de Sá

1083 Do castro de S. João ao Mosteiro de Santa Clara: notícia de uma intervenção arqueológica, em Vila do Conde Rui Pinheiro 
1095 O castro de Ovil (Espinho), um quarto de século de investigação - resultados e questões em aberto

Jorge Fernando Salvador / António Manuel S. P. Silva

1111 O Castro de Salreu (Estarreja), um povoado proto-histórico no litoral do Entre Douro e Vouga

Sara Almeida e Silva / António Manuel S. P. Silva / Paulo A. P. Lemos / Edite Martins de Sá

1127 Castro de Nossa Senhora das Necessidades (Sernancelhe): uma primeira análise artefactual Telma Susana O. Ribeiro

${ }_{1141}$ A cividade de Bagunte. O estado atual da investigação Pedro Brochado de Almeida

1153 Zoomorfos na cerâmica da Idade do Ferro no NW Peninsular: inventário, cronologias e significado Nuno Oliveira / Cristina Seoane

1163 Vasos gregos em Portugal: diferentes maneiras de contar a história do intercâmbio cultural na Idade do Ferro

Daniela Ferreira

1175 Os exotica da necrópole da Idade do Ferro do Olival do Senhor dos Mártires (Alcácer do Sal) no seu contexto regional

Francisco B. Gomes

\section{Antiguidade Clássica e Tardia}

1191 O uso de madeira como combustível no sítio da Quinta de Crestelos (Baixo Sabor): da Idade do Ferro à Romanização Filipe Vaz / João Tereso / Sérgio Simões Pereira / José Sastre / Javier Larrazabal Galarza / Susana Cosme / José António Pereira / Israel Espi

1207 Cultivos de Época Romana no Baixo Sabor: continuidade em tempos de mudança? João Pedro Tereso / Sérgio Simões Pereira / Filipe Santos / Luís Seabra / Filipe Vaz

1221 A casa romana na Hispânia: aplicação dos modelos itálicos nas províncias ibéricas Fernanda Magalhães / Diego Machado / Manuela Martins

1235 As pinturas murais romanas da Rua General Sousa Machado, n. ${ }^{5}$ 1, Chaves José Carvalho

1243 Trás do Castelo (Vale de Mir, Pegarinhos, Alijó) - Uma exploração agrícola romana do Douro

Tony Silvino / Pedro Pereira

1255 A sequência de ocupação no quadrante sudeste de Bracara Augusta: as transformações de uma unidade doméstica Lara Fernandes / Manuela Martins

1263 Os Mosaicos com decoração geométrica e geométrico-vegetalista dos sítios arqueológicos da área do Conuentus Bracaraugustanus. Novas abordagens quanto à conservação, restauro, decoração e datação Maria de Fátima Abraços / Licínia Wrench

1277 “Casa Romana” do Castro de São Domingos (Cristelos, Lousada): Escavação, Estudo e Musealização Paulo André de P. Lemos

1291 A arqueobotânica no Castro de Guifões (Matosinhos, Noroeste de Portugal): O primeiro estudo carpológico

Luís Seabra / Andreia Arezes / Catarina Magalhães / José Varela / João Pedro Tereso 
1305 Um Horreum Augustano na Foz do Douro (Monte do Castelo de Gaia, Vila Nova de Gaia) Rui Ramos

1311 Ponderais romanos na Lusitânia: padrões, formas, materiais e contextos de utilização Diego Barrios Rodríguez

1323 Um almofariz centro-itálico na foz do Mondego

Marco Penajoia

1335 Estruturas romanas de Carnide - Lisboa Luísa Batalha / Mário Monteiro / Guilherme Cardoso

1347 O contexto funerário do sector da "necrópole NO" da Rua das Portas de S. Antão (Lisboa): o espaço, os artefactos, os indivíduos e a sua interconectividade na interpretação do passado Sílvia Loja, José Carlos Quaresma, Nelson Cabaço, Marina Lourenço, Sílvia Casimiro, Rodrigo Banha da Silva, Francisca Alves-Cardoso

${ }_{1361}$ Povoamento em época Romana na Amadora - resultados de um projeto pluridisciplinar Gisela Encarnação / Vanessa Dias

1371 A Arquitectura Residencial em Mirobriga (Santiago do Cacém): contributo a partir de um estudo de caso Filipe Sousa / Catarina Felício

${ }_{1385}$ O fim do ciclo. Saneamento e gestão de resíduos nos edifícios termais de Mirobriga (Santiago do Cacém)

Catarina Felício / Filipe Sousa

1399 Balsa, Topografia e Urbanismo de uma Cidade Portuária Vítor Silva Dias / João Pedro Bernardes / Celso Candeias / Cristina Tété Garcia

1413 No Largo das Mouras Velhas em Faro (2017): novas evidências da necrópole norte de Ossonoba e da sua ocupação medieval Ricardo Costeira da Silva / Paulo Botelho / Fernando Santos / Liliana Nunes

1429 Instrumentos de pesca recuperados numa fábrica de salga em Ossonoba (Faro) Inês Rasteiro / Ricardo Costeira da Silva / Paulo Botelho

1439 A Necrópole Romana do Eirô, Duas Igrejas (Penafiel): intervenção arqueológica de 2016 Laura Sousa / Teresa Soeiro

1457 Ritual, descarte ou afetividade? A presença de Canis lupus familiaris na Necrópole Noroeste de Olisipo (Lisboa)

Beatriz Calapez Santos / Sofia Simões Pereira / Rodrigo Banha da Silva / Sílvia Casimiro / Cleia Detry / Francisca Alves Cardoso

1467 Dinâmicas económicas em Bracara na Antiguidade Tardia Diego Machado / Manuela Martins / Fernanda Magalhães / Natália Botica

1479 Cerâmicas e Vidros da Antiguidade Tardia do Edifício sob a Igreja do Bom Jesus (Vila Nova de Gaia) Joaquim Filipe Ramos

1493 Novos contributos para a topografia histórica de Mértola no período romano e na Antiguidade Tardia Virgílio Lopes

\section{8. Época Medieval}

1511 Cerâmicas islâmicas no Garb setentrional "português": algumas evidências e incógnitas Constança dos Santos / Helena Catarino / Susana Gómez / Maria José Gonçalves / Isabel Inácio / Gonçalo Lopes / Jacinta Bugalhão / Sandra Cavaco / Jaquelina Covaneiro / Isabel Cristina Fernandes / Ana Sofia Gomes 
1525 Contributo para o conhecimento da cosmética islâmica, em Silves, durante a Idade Média Rosa Varela Gomes

1537 Yábura e o seu território - uma análise histórico-arqueológica de Évora entre os séculos VIII-XII José Rui Santos

1547 A encosta sul do Castelo de Palmela - resultados preliminares da escavação arqueológica Luís Filipe Pereira / Michelle Teixeira Santos

1559 A igreja de São Lourenço (Mouraria, Lisboa): um conjunto de silos e de cerâmica medieval islâmica

Andreia Filipa Moreira Rodrigues

1571 O registo material de movimentações populacionais no Médio Tejo, durante os séculos XII-XIII. Dois casos de "sunken featured buildings", nos concelhos de Cartaxo e Torres Novas Marco Liberato / Helena Santos / Nuno Santos

1585 O nordeste transmontano nos alvores da Idade média. Notas para reflexão Ana Maria da Costa Oliveira

1601 Sepulturas escavadas na rocha do Norte de Portugal e do Vale do Douro: primeiros resultados do Projecto SER-NPVD

Mário Jorge Barroca / César Guedes / Andreia Arezes / Ana Maria Oliveira

1619 "Portucalem Castrum Novum" entre o Mediterrâneo e o Atlântico: o estudo dos materiais cerâmicos alto-medievais do arqueossítio da rua de D. Hugo, nํ. 5 (Porto) João Luís Veloso

1627 A Alta Idade Média na fronteira de Lafões: notas preliminares sobre a Arqueologia no Concelho de Vouzela

Manuel Luís Real / Catarina Tente

1641 Um conjunto cerâmico medieval fora de portas: um breve testemunho aveirense Susana Temudo

${ }_{1651}$ Os Lóios do Porto: uma perspetiva integrada no panorama funerário da Baixa Idade Média à Época Moderna em meios urbanos em Portugal

Ana Lema Seabra

1659 O Caminho Português Interior de Santiago como eixo viário na Idade Média Pedro Azevedo

1665 Morfologia Urbana: Um exercício em torno do Castelo de Ourém André Donas-Botto / Jaqueline Pereira

1677 Intervenção arqueológica na Rua Marquês de Pombal/Largo do Espírito Santo (Bucelas, Loures)

Florbela Estêvão / Nathalie Antunes-Ferreira / Dário Ramos Neves / Inês Lisboa

1691 O Cemitério Medieval do Poço do Borratém e a espacialidade funerária na cidade de Lisboa Inês Belém / Vanessa Filipe / Vasco Noronha Vieira / Sónia Ferro / Rodrigo Banha da Silva

1705 Um Espaço Funerário Conventual do séc. XV em Lisboa: o caso do Convento de São Domingos da Cidade Sérgio Pedroso / Sílvia Casimiro / Rodrigo Banha da Silva / Francisca Alves Cardoso

\section{9. Época Moderna e Contemporânea}

1721 Arqueologia Moderna em Portugal: algumas reflexões críticas em torno da quantificação de conjuntos cerâmicos e suas inferências históricas e antropológicas Rodrigo Banha da Silva / André Bargão / Sara da Cruz Ferreira

1733 Faianças de dois contextos entre os finais do século XVI e XVIII do Palácio dos Condes de Penafiel, Lisboa

Martim Lopes / Tomás Mesquita 
1747 Um perfil de consumo do século XVIII na foz do Tejo: O caso do Mercado da Ribeira, Lisboa Sara da Cruz Ferreira / Rodrigo Banha da Silva / André Bargão

1761 Os Cachimbos dos Séculos XVII e XVIII do Palácio Mesquitela e Convento dos Inglesinhos (Lisboa)

Inês Simão / Marina Pinto / João Pimenta / Sara da Cruz Ferreira / André Bargão / Rodrigo Banha da Silva

1775 "Tomar os fumos da erua que chamão em Portugal erua sancta». Estudo de Cachimbos provenientes da Rua do Terreiro do Trigo, Lisboa

Miguel Martins de Sousa / José Pedro Henriques / Vanessa Galiza Filipe

1787 Cachimbos de Barro Caulínitico da Sé da Cidade Velha (República de Cabo Verde)

Rodrigo Banha da Silva / João Pimenta / Clementino Amaro

1801 Algumas considerações sobre espólio não cerâmico recuperado no Largo de Jesus (Lisboa) Carlos Boavida

1815 Adereços de vidro, dos séculos XVI-XVIII, procedentes do antigo Convento de Santana de Lisboa (anéis, braceletes e contas)

Joana Gonçalves / Rosa Varela Gomes / Mário Varela Gomes

1837 Da ostentação, luxo e poder à simplicidade do uso quotidiano: arqueologia e simbologia de joias e adornos da Idade Moderna Portuguesa Jéssica Iglésias

1849 Os amuletos em Portugal - dos objetos às superstições: o coral vermelho Alexandra Vieira

1865 Cerâmicas de Vila Franca de Xira nos séculos XV e XVI Eva Pires

1879 «Não passa por teu o que me pertence». Marcas de individualização associadas a faianças do Convento de Nossa Senhora de Aracoeli, Alcácer do Sal Catarina Parreira / Íris Fragoso / Miguel Martins de Sousa

1891 Cerâmica de Leiria: alguns focos de produção

Jaqueline Pereira / André Donas-Botto

1901 Os Fornos na Rua da Biquinha, em Óbidos Hugo Silva / Filipe Oliveira

1909 A casa de Pêro Fernandes, contador dos contos de D. Manuel I: o sítio arqueológico da Silha do Alferes, Seixal (século XVI) Mariana Nunes Ferreira

1921 O Alto da Vigia (Sintra) e a vigilância e defesa da costa Alexandre Gonçalves / Sandra Santos

1937 O contexto da torre sineira da Igreja de Santa Maria de Loures Paulo Calaveira / Martim Lopes

1949 A Necrópole do Hospital Militar do Castelo de São Jorge e as práticas funerárias na Lisboa de Época Moderna Susana Henriques / Liliana Matias de Carvalho / Ana Amarante / Sofia N. Wasterlain

1963 SAND - Sarilhos Grandes Entre dois Mundos: o adro da Igreja e a Paleobiologia dos ossos humanos recuperados

Paula Alves Pereira / Roger Lee Jesus / Bruno M. Magalhães

1975 Expansão urbana da vila de Cascais no século XVII e XVIII: a intervenção arqueológica na Rua da Vitória no 15 a 17

Tiago Pereira / Vanessa Filipe

1987 Novos dados para o conhecimento do Urbanismo de Faro em época Moderna Ana Rosa 
1995 Um exemplo de Arqueologia Urbana em Alcoutim: o Antigo Edifício dos CTT Marco Fernandes / Marta Dias / Alexandra Gradim / Virgílio Lopes / Susana Gómez Martínez

2007 Palácio dos Ferrazes (Rua das Flores/Rua da Vitória, Porto): a cocheira de Domingos Oliveira Maia

Francisco Raimundo

2021 As muitas vidas de um edifício urbano: História, Arqueologia e Antropologia no antigo Recreatório Paroquial de Penafiel Helena Bernardo / Jorge Sampaio / Marta Borges

2035 O convento de Nossa Senhora da Esperança de Ponta Delgada: o contributo da arqueologia para o conhecimento de um monumento identitário João Gonçalves Araújo / N’Zinga Oliveira

2047 Arqueologia na ilha do Corvo... em busca da capela de Nossa Senhora do Rosário Tânia Manuel Casimiro / José Luís Neto / Luís Borges / Pedro Parreira

2059 Perdidos à vista da Costa. Trabalhos arqueológicos subaquáticos na Barra do Tejo Jorge Freire / José Bettencourt / Augusto Salgado

2071 Arqueologia marítima em Cabo Verde: enquadramento e primeiros resultados do projecto CONCHA

José Bettencourt / Adilson Dias / Carlos Lima / Christelle Chouzenoux / Cristóvão Fonseca / Dúnia Pereira / Gonçalo Lopes / Inês Coelho / Jaylson Monteiro / José Lima / Maria Eugénia Alves / Patrícia Carvalho / Tiago Silva

2085 Trabalhos arqueológicos na Cidade Velha (Ribeira Grande de Santiago, Cabo Verde): reflexões sobre um projecto de investigação e divulgação patrimonial André Teixeira / Jaylson Monteiro / Mariana Mateus / Nireide Tavares / Cristovão Fonseca / Gonçalo C. Lopes / Joana Bento Torres / Dúnia Pereira / André Bargão / Aurélie Mayer / Bruno Zélie / Carlos Lima / Christelle Chouzenoux / Inês Henriques / Inês Pinto Coelho / José Lima / Patrícia Carvalho / Tiago Silva

2103 A antiga fortificação de Quelba / Khor Kalba (E.A.U.). Resultados de quatro campanhas de escavações, problemáticas e perspectivas futuras Rui Carita / Rosa Varela Gomes / Mário Varela Gomes / Kamyar Kamyad

2123 Colónias para homens novos: arqueologia da colonização agrária fascista no noroeste ibérico Xurxo Ayán Vila / José Mạ . Señorán Martín 


\title{
UM ESPAÇO FUNERÁRIO CONVENTUAL DO SÉC. XV EM LISBOA: O CASO DO CON- VENTO DE SÃO DOMINGOS DA CIDADE
}

\author{
Sérgio Pedroso ${ }^{1}$, Sílvia Casimiro ${ }^{2}$, Rodrigo Banha da Silva ${ }^{3}$, Francisca Alves Cardoso 4
}

\begin{abstract}
RESUMO
A intervenção arqueológica da Praça da Figueira, em Lisboa, foi executada entre 1999 e 2001, tendo correspondido a uma acção reativa a um plano municipal de reabilitação e revitalização do espaço público. O conhecimento sobre a fisionomia da área na Baixa Idade Média encontrava-se mal-esclarecido, embora diversa documentação coeva garantisse que correspondia, na maior parte da área escavada, às antigas Hortas do Convento de São Domingos da Cidade, fundado em 1242, e sobre as quais se ergueria a partir de 1492 o Hospital Real de Todos-Os-Santos.

Neste contexto, no ângulo SO da intervenção arqueológica, reconheceu-se uma area murada à qual foi dada uso funerário, e onde foram identificadas oito sepulturas praticadas em covacho sugerindo uma regular gestão do espaço.

Palavras-Chave: Lisboa Medieval, Arqueologia da Morte, Espaços funerários, Arqueologia Conventual, Ordem dos Pregadores.

ABSTRACT

In 1999-2001, an archaeological excavation took place at Praça da Figueira (Lisbon), in response to a municipal plan for the rehabilitation and revitalization of public space. The knowledge about the physiognomy of the area in Late Middle Ages was poorly understood, although several coeval documents ensured it corresponded in most of the area excavated to the vegetable gardens area of the Dominican Convent, founded in the 1242, and on which it would rise, from 1492, the Royal Hospital of All Saints.

It is in this context that a medieval enclosed area was recognized, which in the $15^{\text {th }}$ century, was used for funerary practice. Eight shallow graves were identified, in a framework that suggests a regular spatial management. Keywords: Medieval Lisbon, Archaeology of Death, Burial Ground, Conventual Archaeology, Dominican Order.
\end{abstract}

\section{INTRODUÇÃO}

A Praça da Figueira é um ponto arqueológico de extrema importância para o conhecimento das antigas ocupações de Lisboa, devido à grande quantidade de informação histórico-arqueológica que gera desde a segunda metade do século XX. São em Lisboa mar- cantes os trabalhos da Conservadora de Museus Irisalva Moita, desenvolvidos entre 1960 e 1962, onde hoje se situa a estação do metropolitano do Rossio. Foi aqui que, devido ao seu "acompanhamento" e ulterior escavação, conduzida entre Agosto e Setembro de 1960, se encontraram estruturas pertencentes ao Hospital Real de Todos-os-Santos, anexos do

1. NOVA FCSH, Faculdade de Ciências Sociais e Humanas, Mestrando em Arqueologia; sergiopedroso1998@gmail.com.

2. LABOH, Laboratório de Antropologia Biológica e Osteologia Humana, CRIA, Centro em Rede de Investigação em Antropologia / IEM, Instituto de Estudos Medievais, NOVA FCSH, Faculdade de Ciências Sociais e Humanas, Universidade Nova de Lisboa; scasimiro@fcsh.unl.pt.

3. CAL, Centro de Arqueologia de Lisboa - Câmara Municipal de Lisboa; CHAM, Centro de Humanidades, NOVA FCSH; Departamento de História da NOVA FSCH; rodrigo.banha@cm-lisboa.pt.

4. LABOH, Laboratório de Antropologia Biológica e Osteologia Humana, CRIA, Centro em Rede de Investigação em Antropologia, NOVA FCSH, Faculdade de Ciências Sociais e Humanas, Universidade Nova de Lisboa; Cranfield Defense \& Security, Cranfield University, Reino Unido; francicard@fcsh.unl.pt. 
Convento de São Domingos da Cidade, o Cano Real de São Domingos (Silva, 2005) e se detetou parte de uma necrópole Romana, cuja existência já era antes sugerida por outros pontos arqueológicos próximos (Silva, 2005, p. 3).

Antes das ações de Moita, todavia, já em 1953 o olisipógrafo Gustavo de Matos Sequeira havia posto a descoberto restos da escadaria frontal da Igreja do Hospital Real de Todos-os-Santos no subsolo do estabelecimento comercial "Irmãos Unidos", ainda em considerável bom estado de conservação. Esta descoberta foi notoriamente noticiada na imprensa e alvo de visitas, incluindo a da própria investigadora do Museu da Cidade (Bargão, Ferreira \& Silva, no prelo). Não espanta, deste modo, que em 1960 o andamento das obras do metropolitano na Praça da Figueira tenha sido acompanhado por Moita, que é quem ali despoleta e conduz a primeira grande escavação arqueológica de contextos de Época Moderna em Portugal (Bargão, Ferreira \& Silva, no prelo). Porém, entre a exumação dos restos com aquela cronologia e a deteção dos achados romanos no subsolo, encontrados a muito maior profundidade já em meados de 1961, nada foi registado para as ocupações da Idade Média, que deste modo compuseram um completo vazio de conhecimento arqueológico (Silva, 2011, 2012, 2018).

Em sentido diverso, as únicas referências textuais minimamente discriminatórias relativas às Hortas de São Domingos reportam-se ao instrumento do escambo efetuado já por D. Manuel em 1502 (recorde-se que as obras se iniciaram em 1492 pela mão de D. João II), que explicitamente refere que "(...) fazemos saber que ouvemos do moesteyro de Sam Domingos desta cidade toda a orta e huum celeyro com sua manga que ho dito moesteiro tinha hy jumto pera se no chãao da dicta orta celeyro e manga aver de fazer o espital de Todollos Sanctos (...)"5, ou a descrição e condições de salubridade do terreno prévias e do próprio edifício conventual no século XIII, mencionando a ereção posterior de um muro de cerca, produzida muito mais tardiamente por Fr. Luís de Sousa, na segunda metade do séc. XVI (Sousa \& Cacegas, 1767, pp. 315-318). Como se conclui, o laconismo da documentação medieval e moderna

5. Transcrito de "Carta de D. Manuel sobre a doação por escambo da cerca do Convento de S. Domingos”, 22 Agosto 1502. ANTT, Registo de Escrituras do reinado de D. Manuel I, Liv. 1134, fl.1-2v. [Arquivo Nacional Torre do Tombo]. citada, de forma alguma permitia entrever a densidade de dois séculos e meio de uso do espaço pelos frades dominicanos.

Perante este panorama, a intervenção arqueológica desenvolvida na Praça da Figueira entre 1999 e 2001 representou a primeira ocasião em que se conheceram os vestígios materiais das ocupações medievais no seu todo e em toda a sua riqueza informativa, o que incluiu uma estrada muçulmana, mais de uma dezena de habitações e os quatro arruamentos respetivos de uma secção de um bairro arrabaldino da cidade islâmica (Silva, Gomes \& Gomes, 2011, pp. 19-22; Silva, 2012), vestígios das ocupações da segunda metade do séc. XII e primeira metade do século XIII e, por fim, as dinâmicas correspondentes à Corredoura medieval (que sucedeu no mesmo local à anterior estrada muçulmana (Silva, 2012, p. 141), às parcelas suburbanas setentrionais da antiga Rua da Betesga e, claro está, dos cerca de dois séculos e meio de utilização do terreno das Hortas de São Domingos (Lourinho, 1972, p. 32; Moita, 1994, p. 119; Silva, 2012, p. 10, 2018).

\section{MATERIAIS E MÉTODOS}

Com base nos registos de campo (descritivos, gráficos e estratigráficos), realizou-se uma análise do espaço funerário, considerando-se aspetos como a sua organização, o tipo de inumação, o modo de deposição, a orientação, a tipologia das sepulturas. A amostra osteológica associada a este contexto foi já alvo de estudo, pelo que consequentemente os dados relativos ao perfil biológico aqui apresentados estão de acordo com os da autora (Busom, 2017). No presente trabalho somente os dados referentes ao perfil biológico (e.g. idade à morte e diagnose sexual) são utilizados. A metodologia de análise utilizada pela autora na inferência destes parâmetros biológicos, obedeceu a métodos amplamente utilizados, com foco na análise morfológica dos vários elementos ósseos do esqueleto e níveis de desenvolvimento e maturação óssea (Busom, 2017). Aos indivíduos considerados como "não-adultos" não foi realizada a diagnose sexual, uma vez que dimorfismo sexual é ainda incipiente, e os métodos existentes têm associado um erro significativo ao nível do diagnóstico. $\mathrm{Na}$ apresentação da estimativa da idade à morte será introduzida uma ligeira alteração, relativamente à abordagem apresentada por Busom (2017), na apresentação dos resultados: as classifica- 
ções etárias serão qualitativas, ao invés de quantitativas, procurando assim minimizar-se o erro interpretativo de atribuição de uma cronologia etária com base em alterações ósseas, e fases de maturação e desenvolvimento.

Consequentemente, os indivíduos serão classificados de "não adultos", "adolescentes" e "adultos" contrariamente à classificação cronológica apresentada por Busom (2017). Os esqueletos classificados como sendo de indivíduos "adolescentes" compreendem intervalos etários entre os 11 anos e 18 anos. As questões associadas aos limites interpretativos da inferência do perfil biológico em material ósseo, assim como a reavaliação dos elementos ósseos desta amostra, serão exploradas no âmbito de dissertação de mestrado atualmente em desenvolvimento por um dos autores (S.P.).

\section{O ESPAÇO FUNERÁRIO DA PRAÇA DA FIGUEIRA}

O espaço funerário medieval identificado na intervenção da Praça da Figueira em 1999-2001 situava-se na área inserida nas quadrículas Cio e Ci1, localizadas no exterior do futuro parqueamento automóvel subterrâneo, no ângulo SO da escavação (Silva, 2018 e Figura 1).

Porque situado a uma cota inferior à da fachada do Hospital Real de Todos-os-Santos, esta localização fixa-lhe desde logo um intervalo cronológico superior, considerando aqui que os trabalhos de edificação se desenvolveram a partir de finais do séc. XV, segundo o testemunho produzido em 1545 por Garcia de Resende: "(...) no anno de mil e quatrocentose noventa e dous a quyinze dias do mes de Mayo mandou el-rey [D. João II] perante si fundar e começar os primeiros aliceces do esprital grande de Lixboa da invocaçam de Todolos Sanctos na maneira en que ora está feito, o qual lugar era horta do Moesteiro de Sam Domingos. E nos primeyros aliceces el-rey por sua mão por honrra de tam sancto, tam grande, e tam piadoso edeficio, lançou muytas moedas d'ouro. E esse dia andou todo ahi vendo como se começava e comeo em casa do Conde de Monsanto que he pegada com a horta do dito esprital" (Resende, 1597, cap. CXL).

A documentação histórica é omissa a respeito de edifícios sacros na área precisa onde se revelou o núcleo funerário. A norte da Igreja de São Domingos, fundada em 1242, mas concluída mais tarde, somente no reinado de D. Afonso III, encontrava-se a Ermida de Nossa Senhora da Escada ou de Nossa Senhora da Purificação (Lourinho, 1971, pp. 121-123; 1972, p. 33). Apesar de não existir documentação que date a implementação e construção desta Ermi$\mathrm{da}$, pensa-se que a sua fundação se deva ao primeiro bispo de Lisboa, D. Gilberto de Hastings (Lourinho, 1972, p. 36), pelo que já estaria em funcionamento antes da criação do edifício conventual dominicano (Marado, 2018, p. 65). As referências são, todavia, difusas e discordantes, aventando-se em contrapartida a hipótese da sua trasladação de um local próximo (possivelmente, do Alto da Corredoura) cerca do ano de 1300, altura em que é transportado para a vizinhança do templo dedicado a São Domingos (Lourinho, 1972, pp. 38-39). Ora, não só a cronologia do contexto arqueológico que aqui tratamos é discordante de qualquer destas realidades, por bem mais tardia, como a sua correspondência com a hipotética primeira localização da Ermida é desadequada em face da menção geográfica específica ao "Alto", o que está em desacordo com o que se pode intuir da paleotopografia da Praça da Figueira entre os séculos XII e XV.

A explicação para a presença dos sepultamentos exumados em 2001 terá, por conseguinte, de ser diretamente relacionada com as dinâmicas do complexo conventual dominicano, e terá que se considerar estar omissa das fontes escritas conhecidas até ao momento, o que, se por um lado lhe aumenta o interesse, não deixa, em contrapartida, de por isso colocar compreensíveis limitações.

\section{DADOS CONTEXTUAIS}

A área escavada em C1o/11 equivaleu a um polígono irregular destinado ao acesso pedonal do futuro parqueamento subterrâneo, estando localizado no exterior deste. Previamente à escavação arqueológica foram implantadas as paredes perimetrais de contenção em betão que seccionaram o espaço, naturalmente perturbando os contextos arqueológicos.

Merece especial menção a presença do espesso muro [7016] a Oeste, edificado em forte alvenaria de argamassa rica em cal e ao qual se encontrava adossado, na extremidade NO da zona escavada, uma cantaria oitavada, gótica, muito provavelmente equivalente à ombreira de um vão. $\mathrm{O}$ topo conservado do muro situava-se à cota $7,83 \mathrm{~m}$, tendo o restante da superestrutura sido desmantelado pelos trabalhos de aterro e preparação para a construção do Hospital 
Real de Todos-os-Santos, como antes vimos ocorridos a partir de 1492, bem como sido colmatado pela sua face interna por sucessivos depósitos e uma estrutura negativa (lixeira? [7113]) com destaque para um primeiro depósito [7107], mais espesso, que compõe a sequência (Figuras 2-3).

O lado interior (oriental, orientado para o interior das Hortas de São Domingos), estava apenas rebocado e, ao nível da sua base, próxima dos 6,90 $\mathrm{m}$ de cota absoluta, um aglomerado de pedra de pequena dimensão é relacionável com a ação da sua instalação. Um depósito [7115] foi violado pela abertura dos covachos destinados ao uso funerário e sobrepõe-se ao nível de instalação do muro [7016], pelo que necessariamente as sepulturas lhes serão posteriores. As características construtivas do muro, a despeito da sua maior espessura, são similares às apresentadas pelos restantes muros da cerca conventual identificados, incluindo aqui os muros da manga e os de dois poços hidráulicos ovais, qualquer deles exumados no interior do espaço das hortas (Silva, 2012, p. 5 ; 2018). As estruturas mencionadas, já antes divulgadas, encerram uma cronologia do século XV, que o tipo e exiguidade de "materiais datantes" não permite melhor precisar (Silva, 2018).

Fora do sector que vimos descrevendo, em B6/7, sob as potentes infraestruturas de assentamento da monumental escadaria de acesso à Igreja de Todos-os-Santos, já manuelina e dos últimos anos do século $\mathrm{XV} /$ primeiros do séc. XVI, haviam sido também detetados em 2000 pela intervenção arqueológica da Praça da Figueira. Aqui se somam vestígios de mais duas sepulturas, destruídas quase por completo no decorrer das obras de parqueamento de $1999 \mathrm{e}$ 2001, e na obra de D. Manuel. A cota aproximada era similar à que vimos tratando e permite integrá-las numa mesma realidade, muito embora o espólio osteológico seja claramente insuficiente para a caracterização dos dois indivíduos inumados.

A importância destes vestígios tornados discretos é, todavia, fundamental, por permitir entrever a existência de um uso funerário do espaço ao longo de, pelo menos, $27 \mathrm{~m}$ de extensão, encostados aos limites ocidentais da propriedade conventual. Deverá assinalar-se que de acordo com as observações arqueológicas da escavação, o uso funerário está completamente ausente dos restantes mais de $25 \mathrm{~m}$ que se reconheceram próximo da zona da cerca conventual mais a norte (Silva, 2018, fig. 2).

Retornando à área de C1o/11, e abaixo do nível das sepulturas, foi detetado um piso empedrado com fiada de limitação bem definida pelo lado oeste [7045], já recoberto por depósitos, situado à cota $6,85-6,88 \mathrm{~m}$. O piso estava ligeiramente sobrelevado em relação ao terreno imediatamente confinante para Oeste (já o nível do solo do Rossio medieval), situado cerca de $10 \mathrm{~cm}$ abaixo. Esta estrutura equivale, sem grandes reservas, a uma parcela da estrada nomeada na documentação medieva como "Corredoura": trata-se de um dos principais itinerários de entrada-saída da cidade de Lisboa, cuja origem mais remota se encontra nos inícios do Alto Império Romano, mas que com a feição medieval se fixou somente nos finais do século XI, durante o período de domínio islâmico de Lisboa (Silva, 2012) (Figura 4). A edificação do Hospital Real absorveria urbanisticamente o troço de passagem da Corredoura no Rossio, incorporando-o sob as 35 arcadas do pórtico manuelino da fachada do complexo do Hospital-Convento de São Domingos, numa intenção de aformoseamento do Rossio que, apesar da sua linhagem estética gótica, encerra claro sabor renascentista, desenhando uma fachada para a cidade naquela que foi, afinal, a sua primeira praça propriamente dita.

\section{A ORGANIZAÇÃO DO ESPAÇO FUNERÁRIO}

Os contextos funerários em análise equivalem a oito unidades estratigráficas negativas -U.E.s [7019], [7020], [7021], [7022], [7023], [7024], [7036], [7039] e [7128]. Nelas se assinalou material biológico humano (i.e., esqueletos em articulação e ossos dispersos) à exceção de [7021], onde estes estavam ausentes. Em todas as sepulturas a orientação é, grosso modo, oeste-este (na realidade em torno dos $19^{\circ} \mathrm{NO}$ ), o que não se distancia muito de uma orientação "canónica" (Figura 5).

As sepulturas caracterizavam-se como sendo covachos ovalados, com dimensões bastante variáveis, medindo entre $1 \mathrm{~m}$ e 1,90 $\mathrm{m}$ de comprimento máximo, não considerando aqui as sepulturas [7029] e [7041], cortadas pela construção das paredes de contenção em betão, preservando c, $90 \mathrm{~cm}$ e de $\mathrm{c} .70 \mathrm{~cm}$ de comprimento preservado, respetivamente. As dimensões dos eixos maiores dos covachos detêm uma relação direta com as dimensões dos inumados correspondentes, o que sugere a sua abertura num momento que pouco antecedeu a deposição do defunto. A profundidade total dos covachos situar-se- 
-ia em torno dos $60 \mathrm{~cm}$, embora com uma ligeira variação entre elas, com a mais profunda ([7021]) à cota $6,88 \mathrm{~m}$, e a mais superficial ([7026]) situada nos 7,02 $\mathrm{cm}$. Apesar do especto relativamente regular do espaço fúnebre, o distanciamento lateral entre sepulturas era também variável, entre os $10 \mathrm{~cm}$ e os $65 \mathrm{~cm}$. A despeito da exiguidade da área intervencionada, é fácil perceber-se a articulação da disposição dos covachos em respeito ao muro [7016], que supomos representar um limite da propriedade dominicana no séc. XV. Deste modo, parece existir um primeiro alinhamento a oeste, a que correspondem oito sepulturas, não se podendo afirmar categoricamente a existência de um segundo alinhamento para leste, dado estar somente representado por uma única sepultura; convém ter presente, em sentido inverso, que a instalação em 1999 dos muros de contenção da obra do parqueamento, poderão ter obliterado por completo as hipotéticas outras sepulturas de uma segunda fiada, caso estas se encontrassem um pouco mais para leste. Certo é, que mais para o interior do espaço medievo das Hortas de São Domingos (para leste) não se documentou qualquer uso funerário, pelo que se define assim in absentia a extensão deste. Em todo o caso, a disposição relativamente regular dos sepultamentos, como a inexistência de cerceamentos pela abertura de covachos mais recentes sugere uma efetiva e cuidadosa gestão do espaço funerário que, sublinhe-se, foi destinado a inumações individuais primárias. Este último aspeto assume alguma relevância se se comparar o caso em estudo com o identificado próximo, no adro da Igreja de São Domingos, em escavações dirigidas por Dias Diogo em 1991, onde foram identificadas sepulturas múltiplas, com dois a quatro indivíduos (Trindade \& Diogo, 2000, p. 6o; Trindade et alii, 2001, p. 109). Deverá assinalar-se, também, que ao nível da visibilidade externa das sepulturas, i.e., ao nível do solo coevo, nenhuma evidência arqueológica foi reconhecida, quer direta, quer relacionável. Os tipos de sinalização à superfície, de sepulturas individuais em covachos datados da Baixa Idade Média mais conhecidos arqueologicamente para na região equivalem à utilização de estelas (Oliveira, 2006, p. 217), de elementos pétreos nas suas muito variadas configurações, ou de um e outro combinados. A despeito dos tipos regionais identificados, de que se poderiam citar os exemplos coevos de Arruda dos Vinhos (Antunes-Ferreira, Cardoso \& Santos, 2013, p. 1113) ou São Miguel de Odrinhas (Coelho,
2006-2007, pp. 128-130), poder-se-á considerar alternativamente, a utilização de materiais perecíveis, mas é matéria que coloca especiais dificuldades de rastreamento em processo de escavação e que, por outro lado, raramente é considerada na Arqueologia Medieval de Lisboa. Deverá sublinhar-se que a ausência das evidências arqueológicas da sinalização à superfície das sepulturas na necrópole objeto deste trabalho corresponde tão somente a um vazio de informação, porque forçosamente se praticou neste cemitério uma cuidada gestão do espaço fúnebre, que o respeito colocado no distanciamento entre as sepulturas identificadas comprova.

Noutro sentido, nenhum elemento artefactual foi encontrado em associação com os inumados, o que na aparência poderia estar a sugerir um baixo nível socioeconómico dos sepultados. Este tipo de inferências, porém, deve ser bastante relativizado, para mais no caso presente considerando estarmos num quadro conventual de uma ordem mendicante. Ora, e não se tratando os sepultados de religiosos dominicanos, por haver elementos não adultos e femininos assinalados, a associação de elementos artefactuais como base para inferências de status perde qualquer sentido neste caso (como noutros) em função dos potenciais contornos mentais e devocionais dos indivíduos e da sua necessária relação com a regra mendicante que prega a pobreza e o despojo de bens como virtude, como é o caso dos dominicanos.

\section{PERFIL BIOLÓGICO DOS INDIVÍDUOS}

De acordo com Busom (2017), neste espaço funerário, os indivíduos encontram-se orientados de oeste para leste, em decúbito dorsal com os membros superiores fletido sobre o tórax, e os inferiores estendidos paralelamente (Figuras 6-9). Relativamente ao perfil biológico, foram identificados quatro adultos (um masculino e três femininos), dois adolescentes e um não adulto (Figura 10) (Busom, 2017, p. 30).

\section{DISCUSSÃO}

O uso funerário do espaço objeto do presente trabalho acarreta algumas implicações interpretativas, dado que na Idade Média o sepultamento cristão era praticado em espaço considerado como sagrado, ou seja, no interior ou imediações de edifícios religiosos (Barroca, 1987, p. 24; Cunha, 2017, p. 72; Antunes-Ferreira, Cardoso \& Santos, 2013, p. 1113). 
Ora, neste sentido, a despeito de nenhuma evidência documental nos documentar nesta zona das hortas conventuais de São Domingos a existência de qualquer espaço sacralizado, ou de a intervenção arqueológica não ter revelado qualquer tipo de outras evidências categóricas neste sentido, terá que se admitir a existência de tal sacralização. Convém, a este propósito, relembrar que a dimensão arquitetónica de um espaço desta natureza poderia ser tipologicamente muito variável, incluindo capelas ou pequenos oratórios (Bencatel, 2009, p. 210), geralmente situados em zonas periféricas ou até limítrofes da cerca conventual. Tal parece ser o caso detetado arqueologicamente em São Domingos da Cidade, e talvez assim se explicando a relativa robustez do muro de limite conventual e a existência de um vão/fenestração nele, composto por elementos arquitetónicos do gótico tardio de que se reconheceu apenas a base de uma ombreira.

Uma outra dimensão interpretativa do núcleo funerário do Convento de São Domingos assoma num outro sentido, histórico.

O estudo monográfico de Luís Ribeiro Gonçalves (2011) sobre a zona lisboeta dos Restauradores Rossio - Praça da Figueira - Martim Moniz na Idade Média veio mostrar, com base documental bastante consistente, que nesta área periurbana da cidade onde se implantaria na década de 1240 o Convento de São Domingos, se concentravam em matéria de propriedade os principais elementos do poder urbano, pois, “(...) entre cónegos regrantes, cavaleiros de Santiago, monges cistercienses e mendicantes, passando pelo clero secular e pelo próprio monarca, aqui estão presentes quase todas as principais instituições da cidade, se não mesmo do Reino" (Gonçalves, 2011, p. 102, p.142). Zona a um tempo marginal e polarizadora, o seu peculiar interesse prendeu-se com as muito boas acessibilidades, a elevada disponibilidade hídrica e a boa aptidão agrícola para o regadio, estando cumulativamente numa posição estratégica em relação à principal estrada de acesso e em relação ao Rossio como entidade urbana.

É o interesse desta zona que motivará, decerto, as tensões entre os vários poderes urbanos terratenentes ali representados, e que de alguma forma poderá ajudar a justificar o tipo de registo arqueológico revelado pela intervenção de 1999-2001. Assim, o achado do piso da corredoura medieval (que poderá datar dos finais do séc. XIII aos inícios do séc. XV) documenta, de forma cabal, que o espaço em causa era espaço público da cidade no período da sua construção, em última instância tutelado pelo monarca. Assim sendo, a edificação de um novo muro de limite da propriedade dos pregadores significará uma ação de apropriação marginal do terreno pela Ordem de São Domingos, episódio ocorrido algures durante o séc. XV. Será neste quadro, por conseguinte, que se terá que perspetivar a utilização da área apropriada com finalidade funerária. Porque os preceitos religiosos exigem que o sepultamento cristão seja praticado em solo sagrado, a utilização da área como funerária consubstanciaria o carácter religioso do solo e inviabilizaria a sua reclamação como terreno público, correspondendo deste modo a uma estratégia de materialização da apropriação por parte dos Dominicanos, afinal depois desfeita em 1492-1502 aquando a construção do Hospital Real de Todos-Os-Santos, que retoma o traçado anterior e implicitamente devolve a parcela de terreno ao domínio público.

\section{FONTES}

\section{Fontes Manuscritas}

Arquivo Nacional Torre do Tombo.

Registo de Escrituras do Reinado de D. Manuel I. Liv. 1134, fl. 1-2v.

\section{BIBLIOGRAFIA}

ANTUNES-FERREIRA, Nathalie; CARDOSO, Guilherme; SANTOS, Filipa (2013) - A Necrópole Medieval/ Moderna de Arruda dos Vinhos. In ARNAUD, José; MARTINS, Andrea; NEVES, César, Coords. - Actas do I Congresso da Associação de Arqueólogos Portugueses "Arqueologia em Portugal-15o anos", Lisboa: Associação dos Arqueólogos Portugueses, pp. 1111-1117.

BARGÃO, André; FERREIRA, Sara; SILVA, Rodrigo Banha da (no prelo) - Memórias de duas intervenções: o remanescente do Hospital Real de Todos-Os-Santos em 1960-1961 e 1999-2001. In Musa, 2, Atas do Colóquio de Homenagem a Irisalva Moita. Lisboa: Egeac, Museu de Lisboa.

BARROCA, Mário Jorge (1987) - Necrópoles e Sepulturas Medievais de Entre-Douro-e-Minho (Séc. V a XV). Porto: Faculdade de Letras da Universidade do Porto (Dissertação para Provas Públicas de Capacidade Científica).

BENCATEL, Diana (2009) - Sarcófagos e Sepulturas medievais (Maia e Matosinhos): análise tipológica e cronológica. In Revista Portuguesa de Arqueologia, Lisboa: Direção Geral do Património Cultural, 12:2, pp. 209-238.

BUSOM, Julia (2017) - Late Medieval Lisboa. Seven Individuals from Praça da Figueira. Cranfield: Universidade 
de Cranfield (Dissertação de Mestrado em Antropologia e Arqueologia Forense).

COELHO, Catarina (2006-2007) - Ruínas Arqueológicas de São Miguel de Odrinhas: a propósito da Campanha de 1997. In Arqueologia e História, Lisboa: Associação dos Arqueólogos Portugueses, Série 12, 58/59, pp. 119-142.

CUNHA, Mário (2017) - O Espaço Eclesial como local de sepultura: As visitações quinhentistas às Igrejas da Ordem de Santiago. In ROSAS, Lúcia; SOUSA, Ana Cristina; BARREIRA, Hugo, Coords. - Actas do Congresso "Genius Loci: Lugares e Significados / Places and Meanings", Porto: CITEM, Vol. 1, pp. 71-84.

DIOGO, António Dias; TRINDADE, Laura (1999) - Estudos Arqueológicos Efectuados pelo G.T.T.R.L. no Martim Moniz e sua Envolvente. In Olisipo, Série II, 8, Lisboa: Associação dos Amigos de Lisboa, pp. 44-54.

FR. LUÍS DE SOUSA; FR. LUÍS CACEGAS (1767) - Primeira Parte da História de S. Domingos particular do Reino e Conquistas de Portugal. Lisboa: Officina de Antonio Rodrigues Galhardo.

GONÇALVES, Luís Ribeiro (2011) - Sistemas de povoamento e organização territorial: dois vales na periferia de Lisboa (séculos IX-XIV). Lisboa: Faculdade de Letras da Universidade de Lisboa (Dissertação de Mestrado em História Medieval). (policopiado).

LOURINHO, Manuel (1971) - A Igreja e o Convento de S.

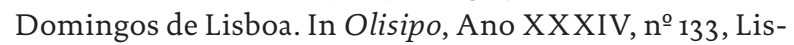
boa: Associação dos Amigos de Lisboa, pp.115-123.

LOURINHO, Manuel (1972) - A Ermida de Nossa Senhora da Escada nas suas relações com a Igreja e o Convento de S. Domingos. In Olisipo, Ano XXXV, no 134, Lisboa: Associação dos Amigos de Lisboa, pp. 32-45.

MARADO, Catarina (2018) - Arquitetura Conventual e Cidade Medieval: a Formação e os Impactos dos sistemas urbanísticos mendicantes em Portugal (Séc. XIII-XV). Coimbra: Imprensa da Universidade de Coimbra.

MOITA, Irisalva (1994) - O Hospital Real de Todos-os-Santos. In Exposição: Lisboa Subterrânea, Lisboa: Museu Nacional de Arqueologia, pp. 118-125.

OLIVEIRA, Ana (2006) - Cabeceiras de Sepultura do Concelho de Loures. In Actas do VIII Congresso Internacional de Estelas Funerárias, Suplemento n⿳ㅜㅜㅇ de O Arqueólogo Português, Lisboa: Museu Nacional de Arqueologia, pp. 215-238.

RESENDE, Garcia de (1596) - Chronica que tracta da vida e grandíssimas virtudes [...] de Dom João o Segundo. Lisboa: Casa de Simão Lopez.

SILVA, Rodrigo Banha da (2005) - "Marcas de Oleiro" em terra sigillata da Praça da Figueira (Lisboa): Contribuição para o conhecimento da economia de Olisipo (Séc. I a.C. - Séc. II d.C.). Minho: Instituto de Ciências Sociais da Universidade do Minho (Dissertação de Mestrado em Arqueologia).

SILVA, Rodrigo Banha da (2012) - A Ocupação do Período da Dominação Islâmica na Praça da Figueira (Lisboa). In SALVADO, Sallete, Coord. - Actas do Colóquio "Afonso I de Portugal nos 9 oo anos do seu nascimento", Lisboa: Associação dos Amigos de Lisboa, pp. 137-147.

SILVA, Rodrigo Banha da (2018) - O Convento de São Domingos, em Lisboa, e a leitura arqueológica das suas hortas, entre os séculos XIII e XV. In ANDRADE, Amélia Aguiar; TENTE, Catarina; SILVA, Gonçalo Melo da; PRATA, Sara, Coords. - Espaços e poderes na Europa urbana medieval. Castelo de Vide: IEM/FCSH/NOVA, Câmara Municipal de Castelo de Vide (col. Estudos, 18), 2018, pp. 553-569.

SILVA, Rodrigo Banha da, GOMES, Mário Varela; GOMES, Rosa Varela (2011) - O Bairro Islâmico da Praça da Figueira (Lisboa). In GOMES, Mário Varela, GOMES, Rosa Varela; TENTE, Catarina, Coords. - Actas do Colóquio "Cristãos e Muçulmanos na Idade Média Peninsular: Encontros e Desencontros”, Aljezur/ Lisboa: IAP, pp. 17-26.

TRINDADE, Laura; DIOGO, António Dias (200o) - Elementos sobre o cemitério do Adro da Igreja de S. Domingos. In Arqueologia e História: Estudo de Lisboa-Séculos XV a XIX: I Colóquio Temático, Lisboa: Associação dos Arqueólogos Portugueses, Série 11, 52, pp. 59-71.

TRINDADE, Laura; LOPES, Luís; NETO, José; DIOGO, António Dias (2001) - Elementos para o estudo dos restos humanos da intervenção arqueológica de 1991 no cemitério do adro da Igreja de São Domingos em Lisboa. In Arqueologia e História, Lisboa: Associação dos Arqueólogos Portugueses, Série 11, 53, pp.109-124. 


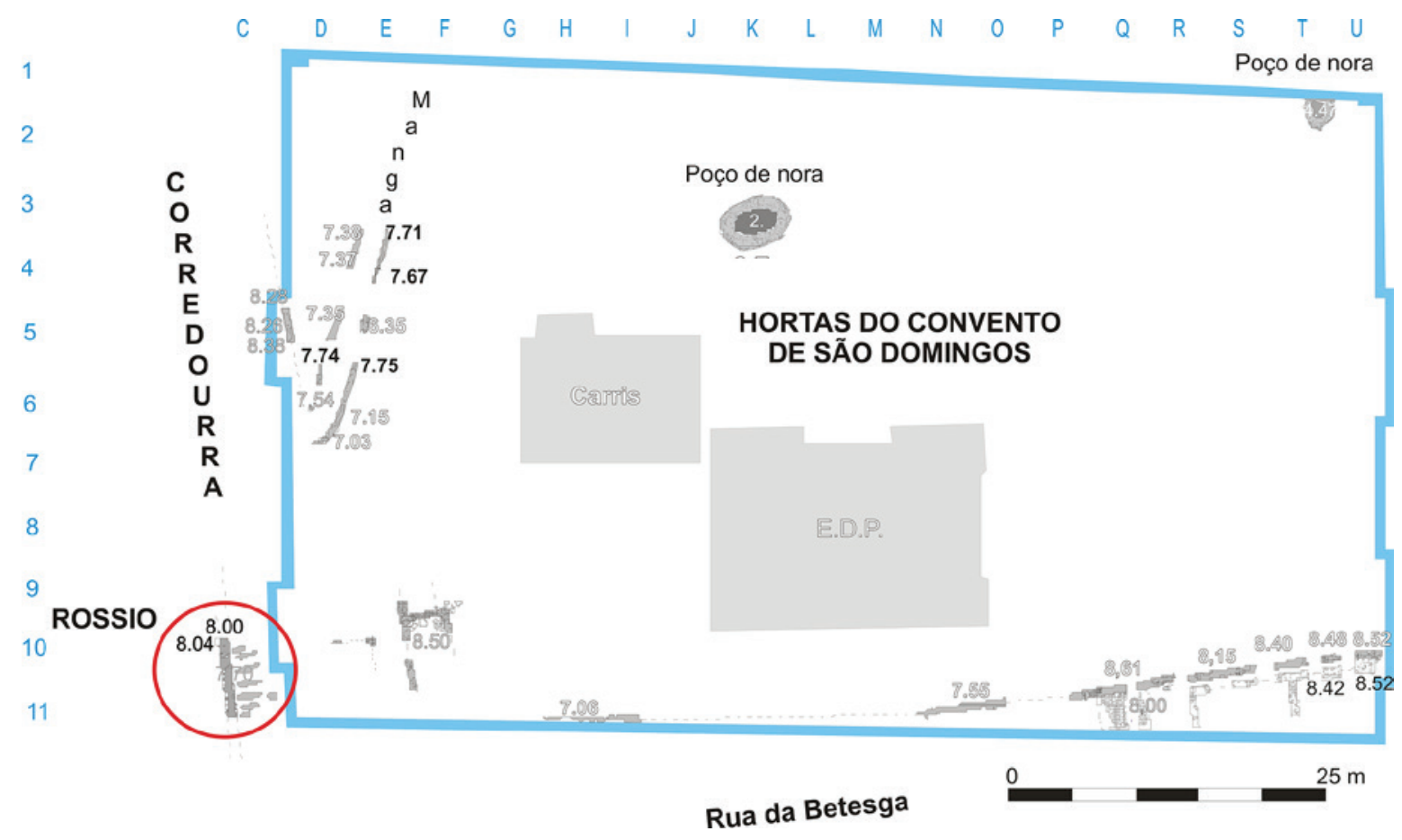

Figura 1 - Área intervencionada na Praça da Figueira (1999-2001) - localização do espaço funerário.

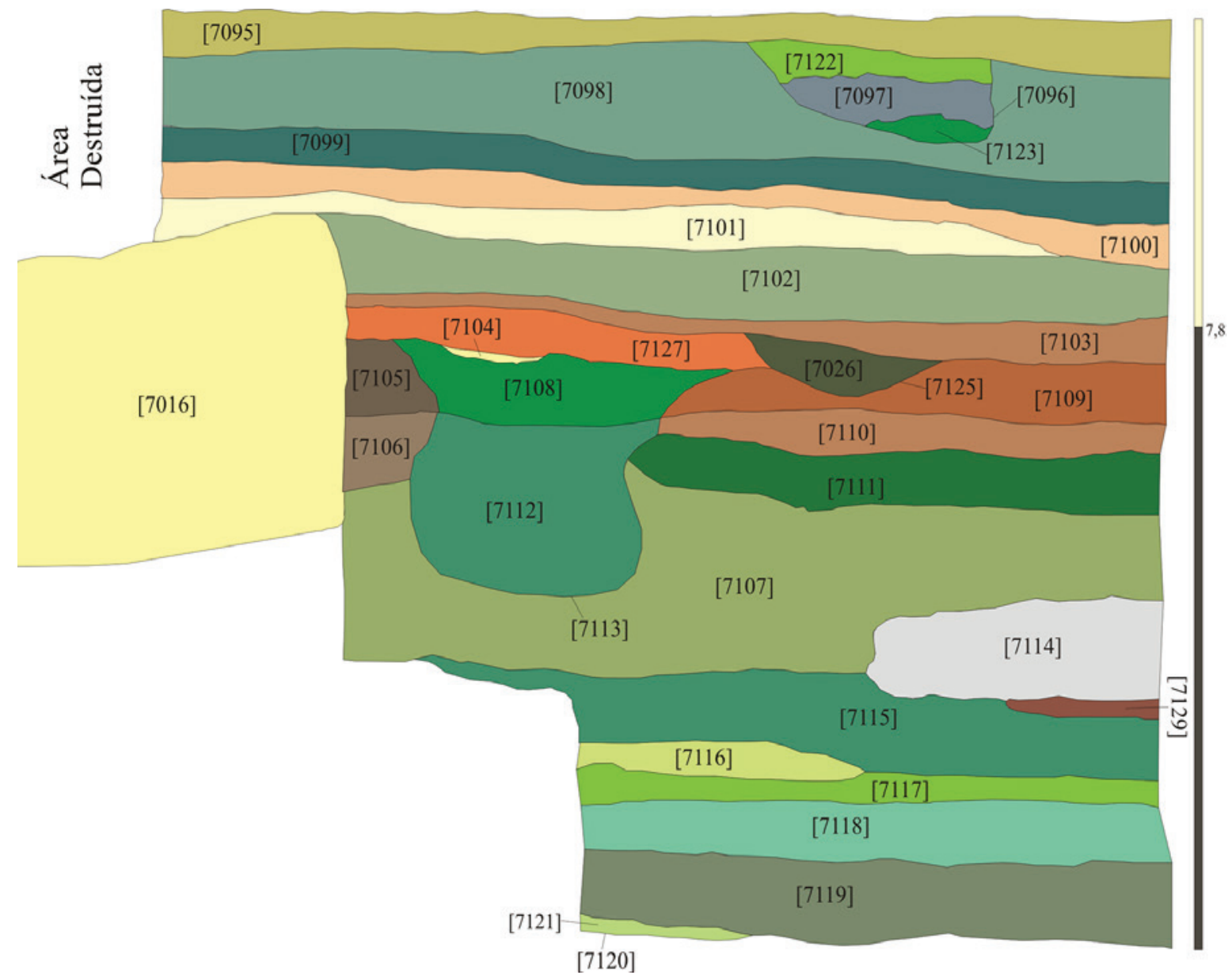

Figura 2 - Perfil Norte de C11. 


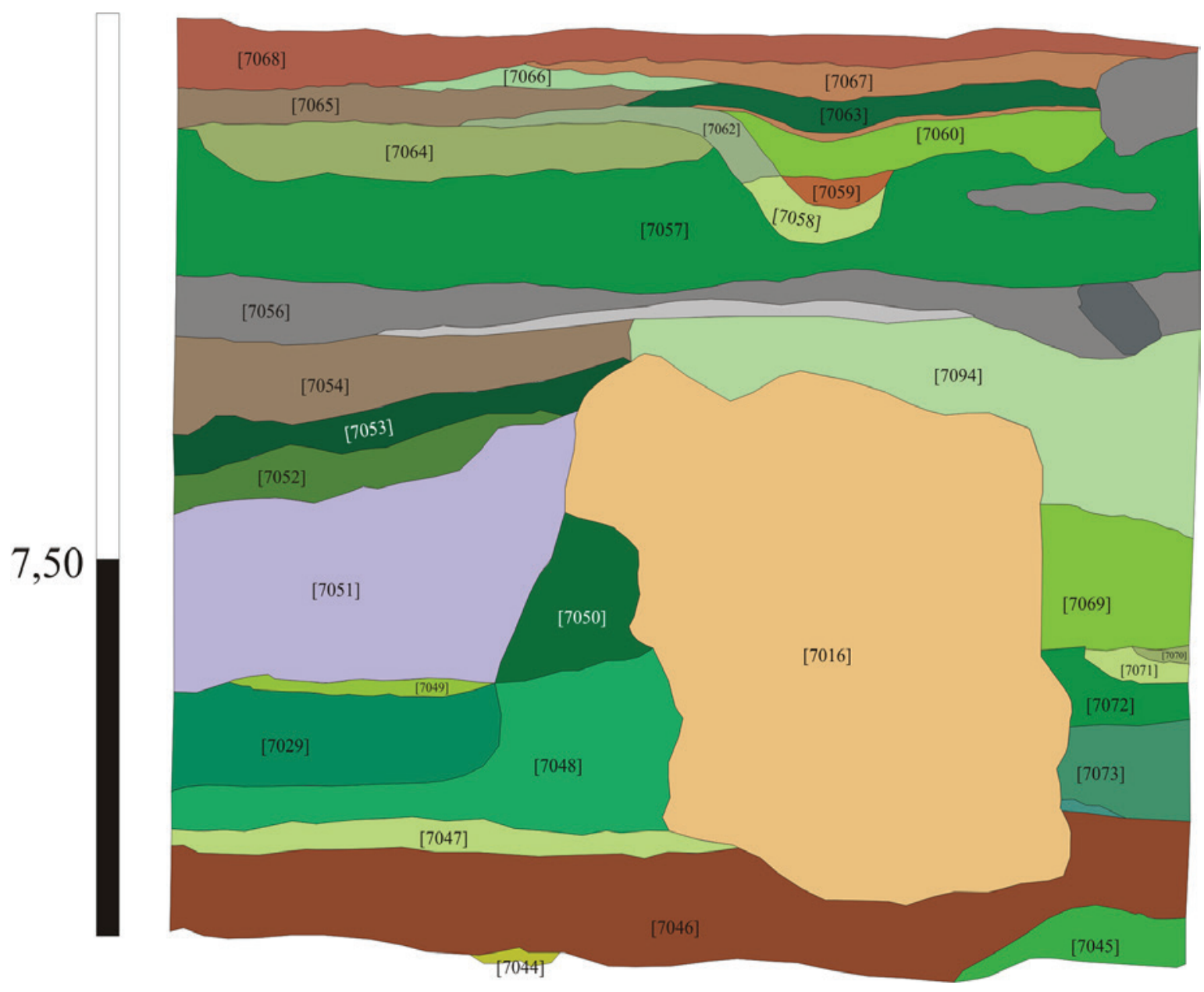

Figura 3 - Perfil Sul de C11

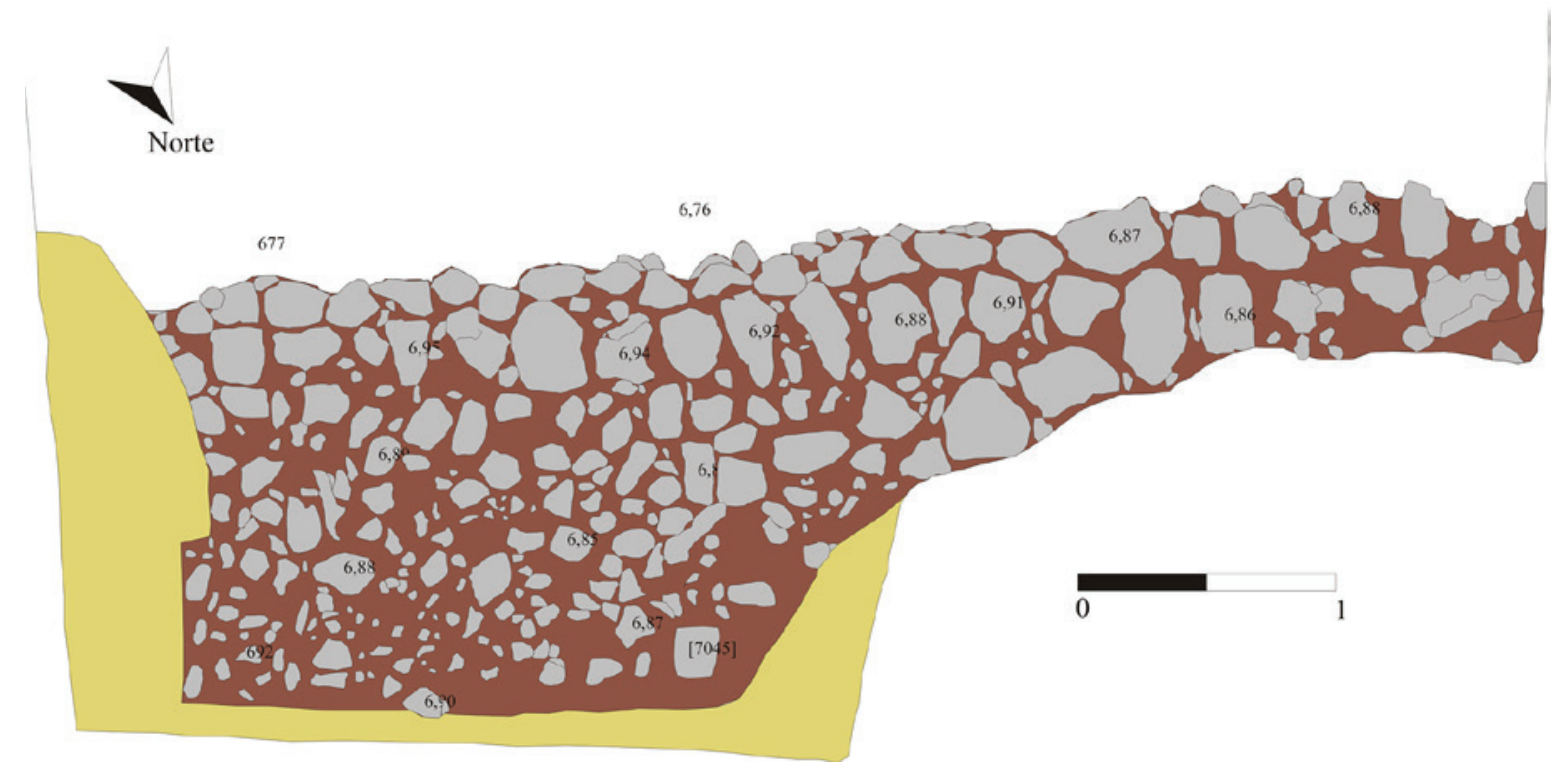

Figura 4 - Plano Geral do troço da Corredoura Medieva - Quad. Ci1, escala 1:20. 


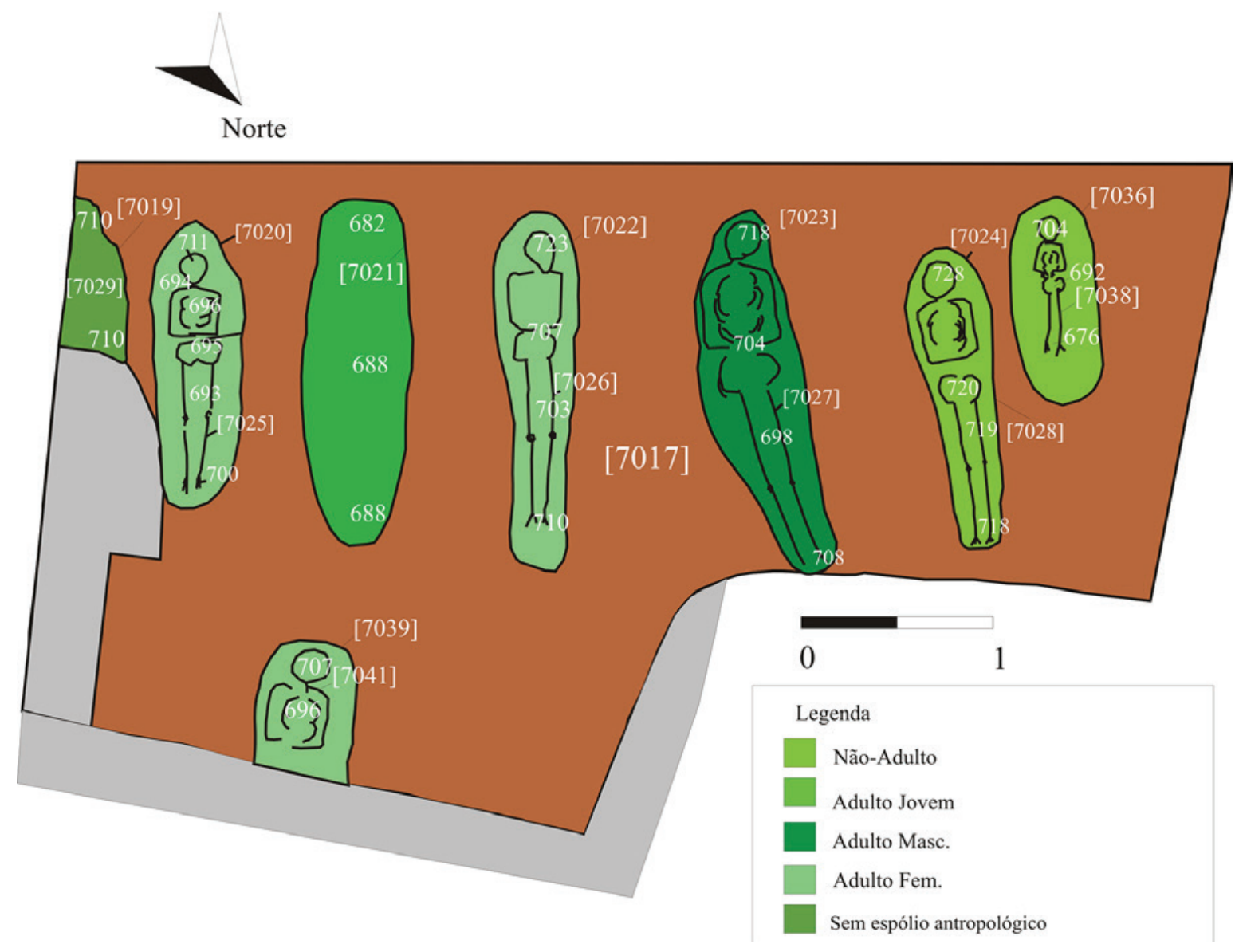

Figura 5 - Plano Geral de C11, Distribuição das sepulturas e perfil biológico dos Indivíduos, escala 1:20. 


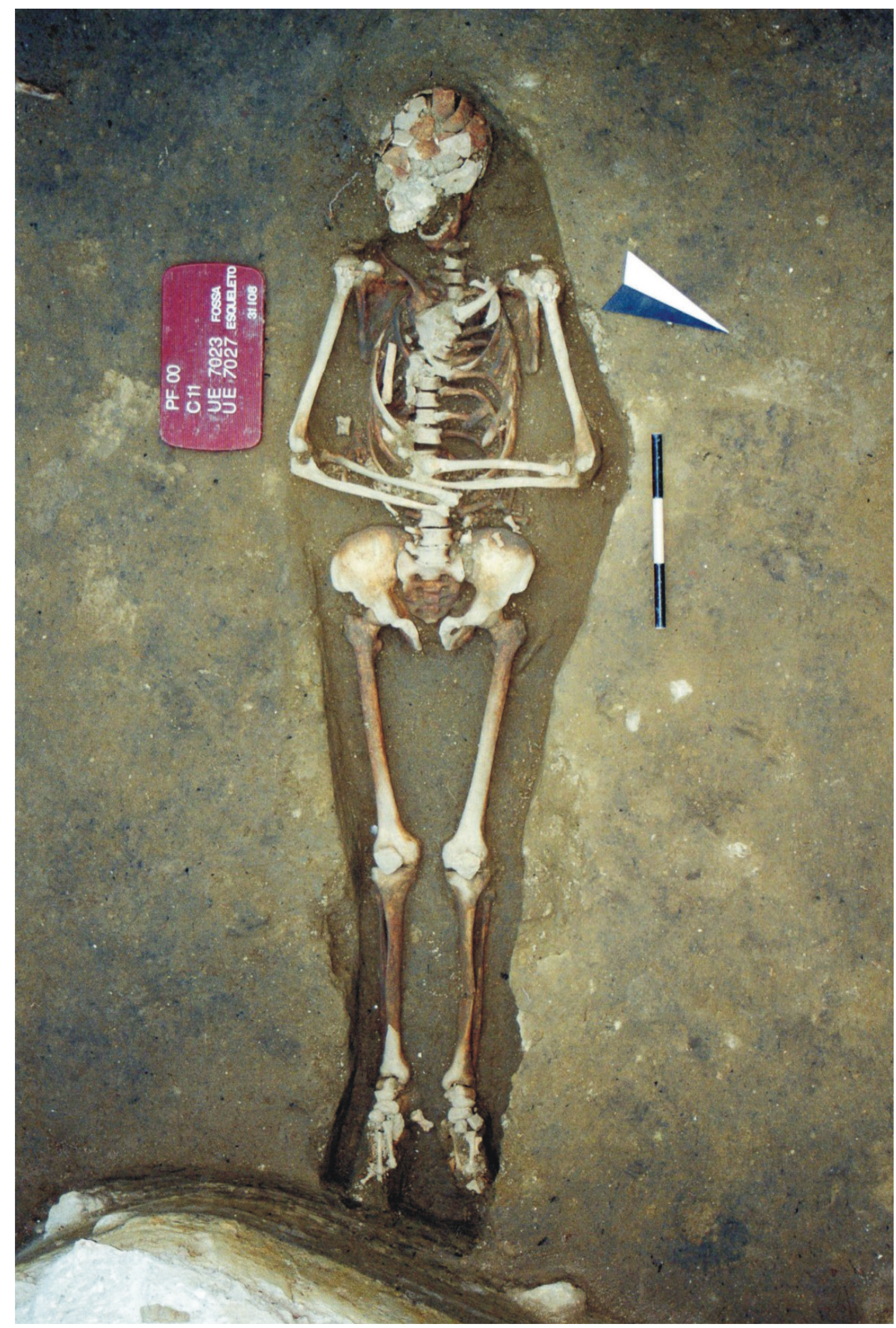

Figura 6 - Sepultura [7023], indivíduo [7027]. 


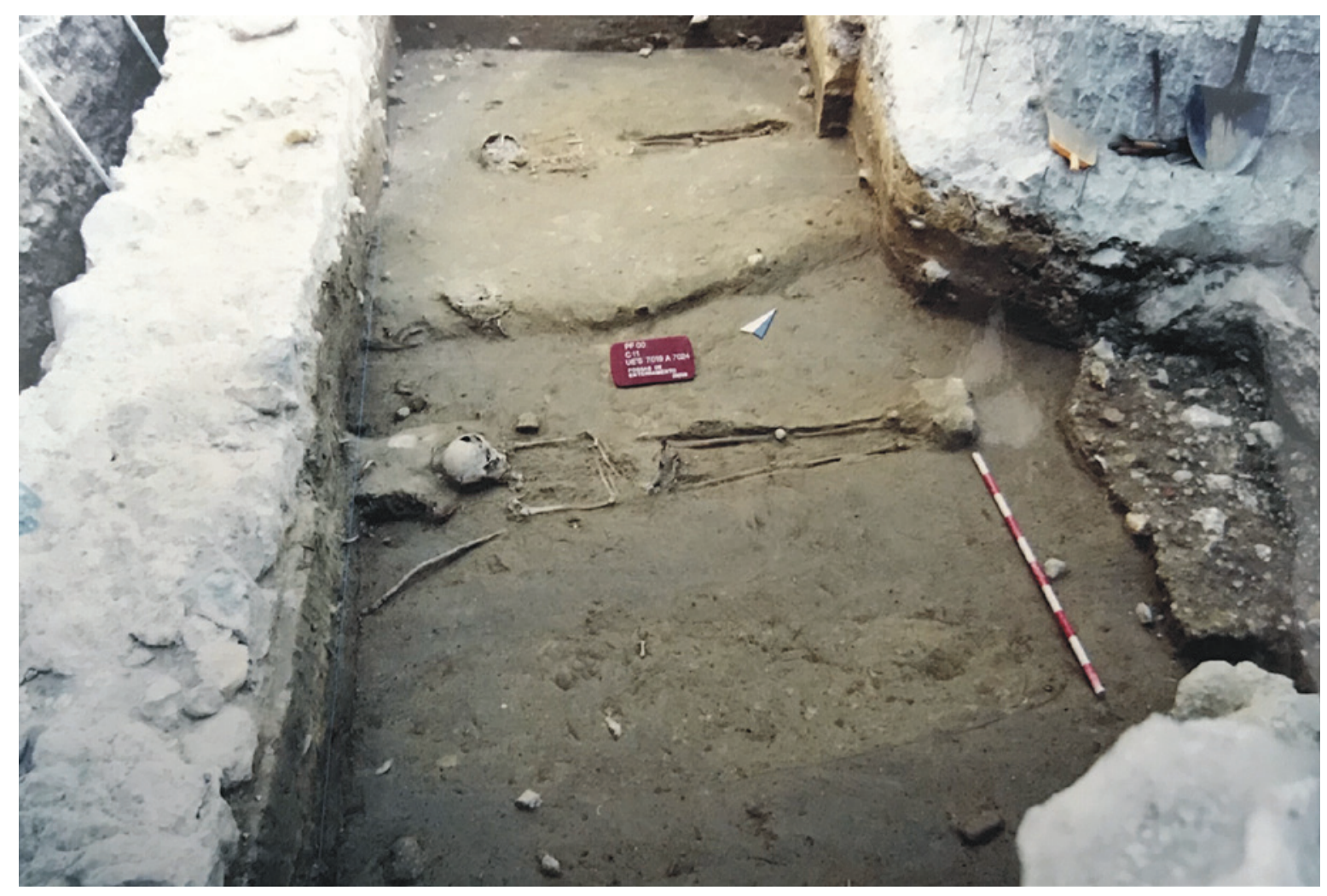

Figura 7 - Vista do espaço funerário, U.E.s [7019] a [7024].

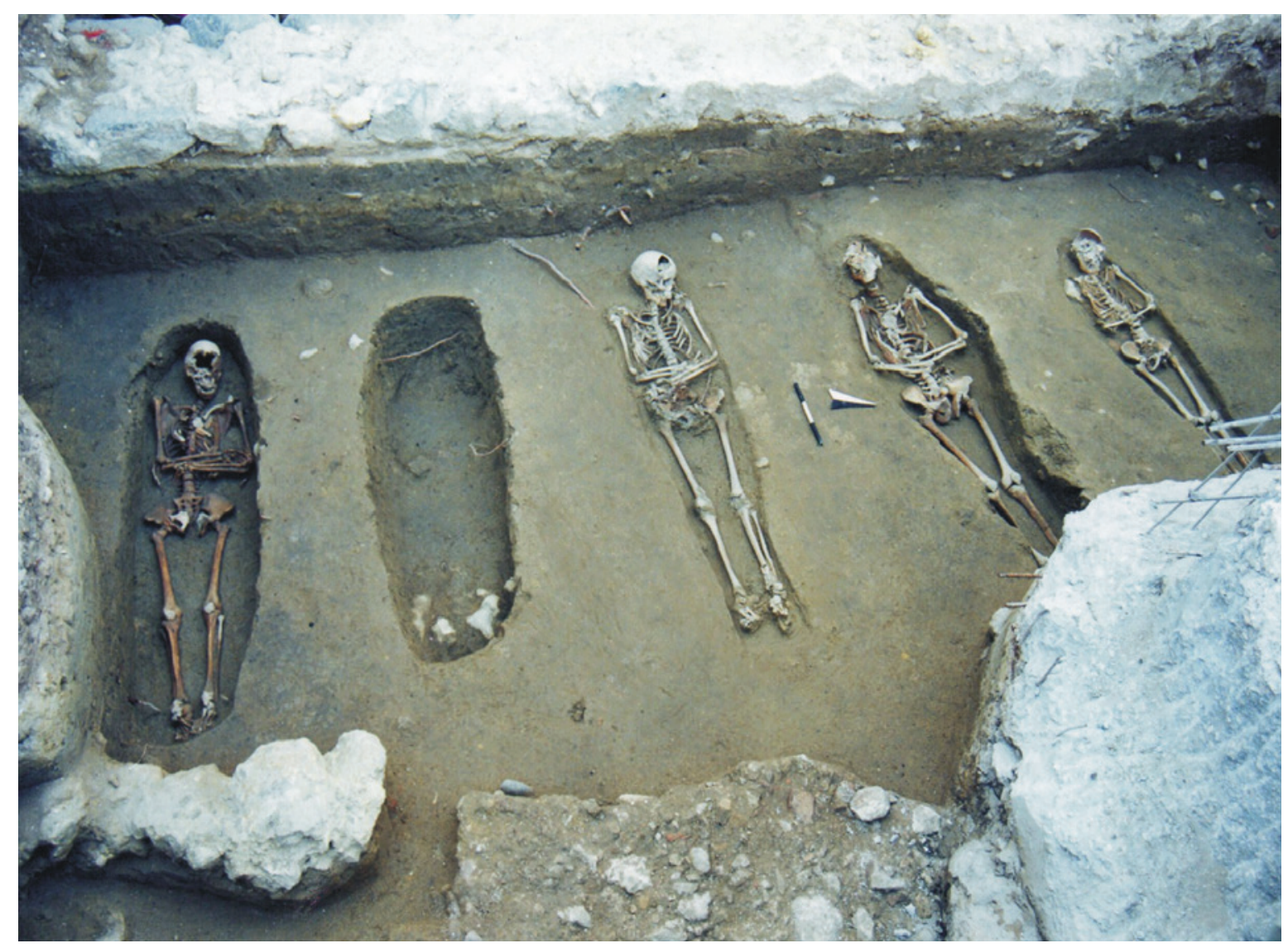

Figura 8 - Vista geral do espaço funerário. 


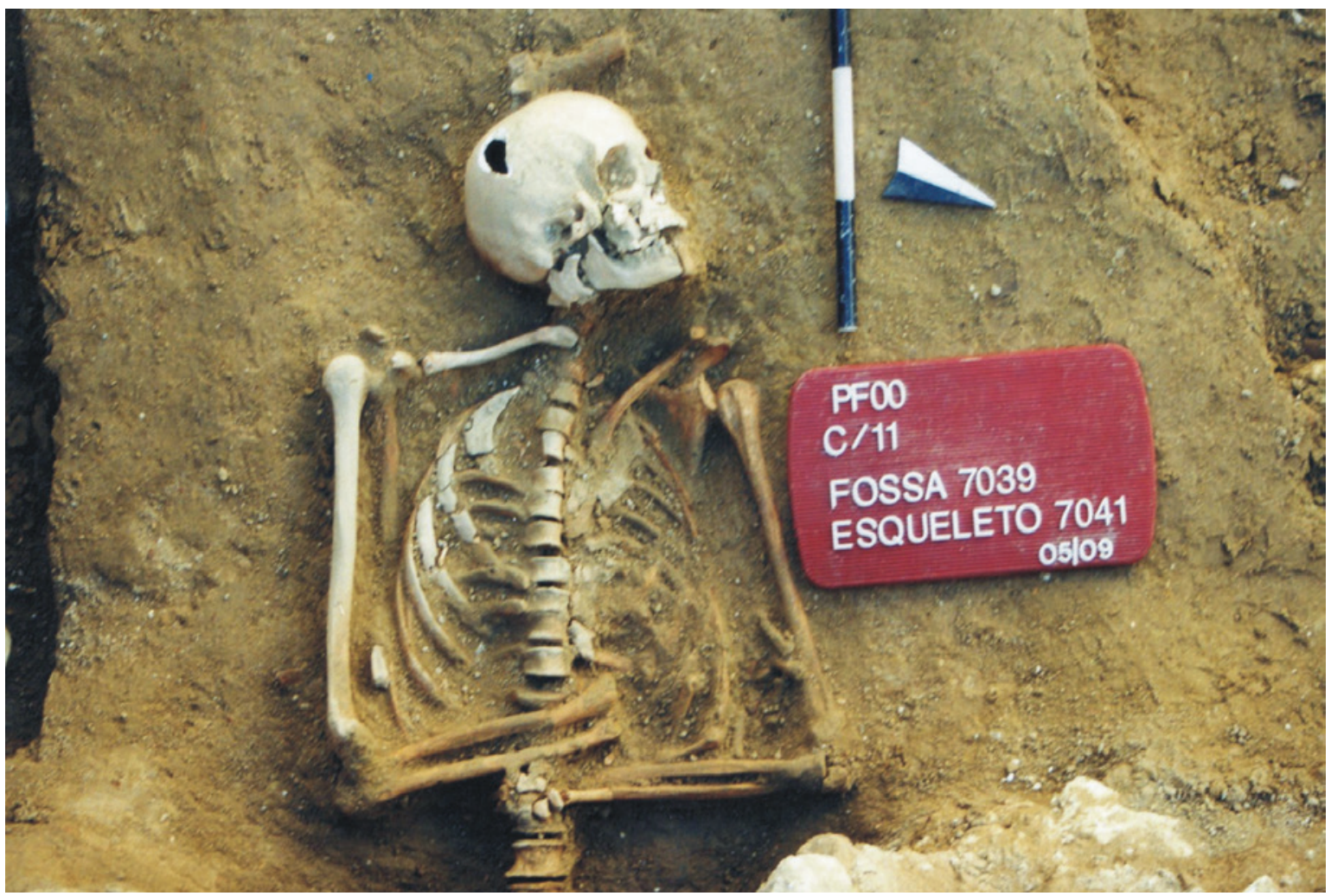

Figura 9-Sepultura [7039], indivíduo [7041] .

\begin{tabular}{|l|l|l|}
\hline Indivíduo & Diagnose Sexual & Categoria Etária \\
\hline$[7025]$ & Feminino & Adulto \\
\hline$[7026]$ & Feminino & Adulto \\
\hline$[7027]$ & Masculino & Adulto \\
\hline$[7028]$ & Indeterminado & Adolescente \\
\hline$[7038]$ & Indeterminado & Não Adulto \\
\hline$[7041]$ & Feminino & Adulto \\
\hline$[7128]$ & Indeterminado & Adolescente \\
\hline
\end{tabular}

Figura 10 - Perfil Biológico (adaptado de Busom, 2017). 


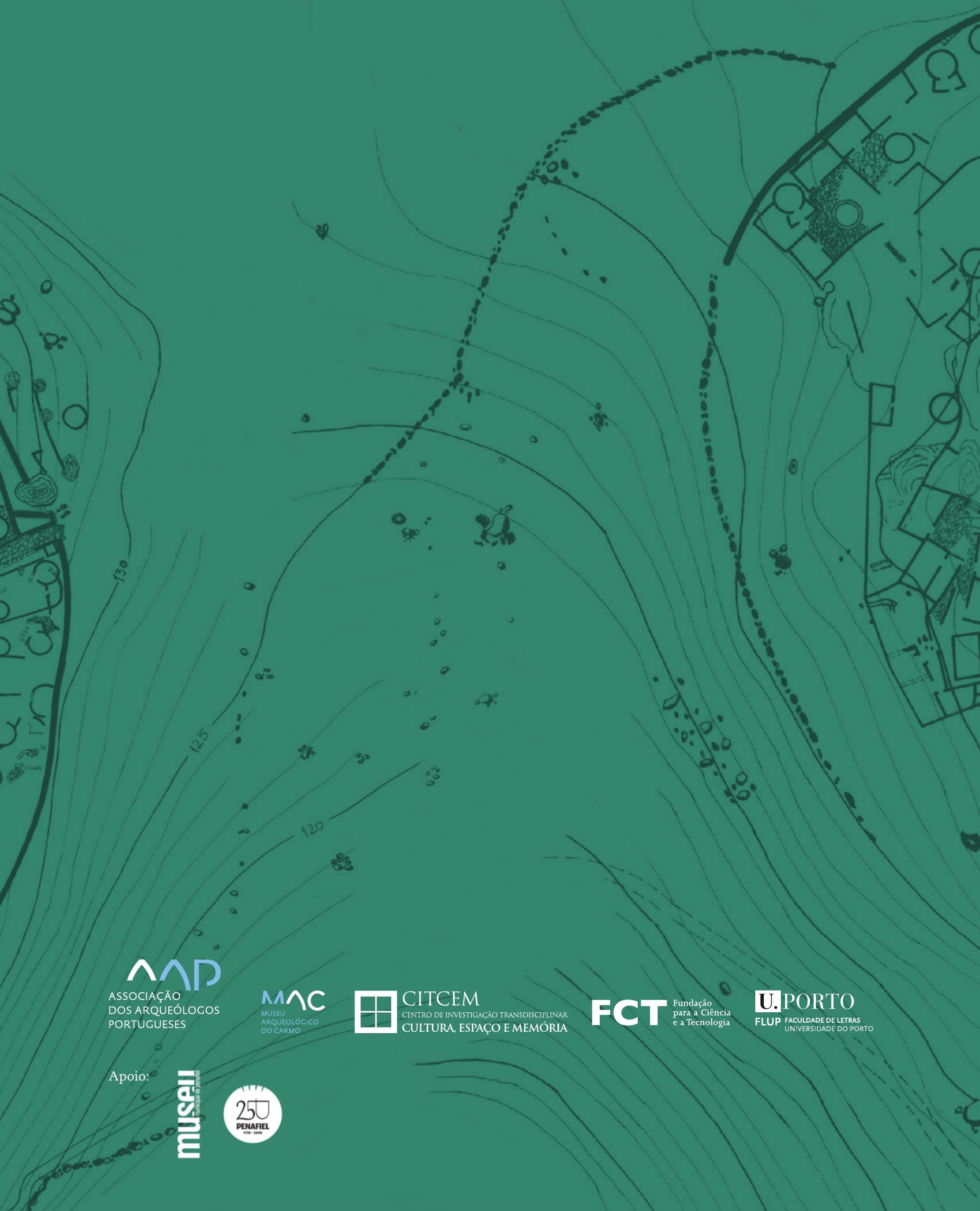

